\title{
Kişiliğin Karanlık Üçlüsü: Narsisizm, Makyavelizm ve Psikopati
}

\author{
Seren Saltoğlu \\ Bahçeşehir Üniversitesi
}

\author{
Doruk Uysal Irak
}

Bahçeşehir Üniversitesi

\begin{abstract}
Özet
Bu derleme çalışmada, son yıllarda alan yazında sıklıkla karşılaşılan ve Karanlık Üçlü başlığı altında incelenen üç kişilik özelliği, Narsisizm, Makyavelizm ve Psikopati ele alınmıştır. Alan yazında Karanlık Üçlü kişilik özellikleriyle yapılan araştırmaların çoğunda bu özeliklerin alt boyutlarının ele alınmadığı görülmektedir. Nitekim bu kişilik özellikleri için alt boyutlar oldukça önemli farklı özellikleri temsil etmektedir. Bu bağlamda derleme çalışmamızın temel amacı bu farklı boyutları ele alarak kişilik özelliklerinin benzerliklerini ve farklılıklarını incelemektir. Bu karşılaştırmalar yapılırken aynı zamanda Narsisizm, Makyavelizm ve Psikopati kişilik özelliklerinin ölçümünde kullanılan ölçüm araçları, diğer kişilik modelleriyle, baş etme stilleriyle ve iyi oluş haliyle olan ilişkileri de bu derlemede özetlenmiştir. Son olarak ileride bu konuda yapılacak çalışmalara ilişkin konulara dikkat çekilerek, bazı önerilerde bulunulmuştur.
\end{abstract}

Anahtar kelimeler: Karanlık Üçlü, Narsisizm, Makyavelizm, Psikopati

\begin{abstract}
In this literature review paper, three traits Narcissism, Machiavellianism and Psychopathy, which have been studied frequently in the field recently with the name of Dark Triad were discussed. In the literature most of the studies testing three traits did not include the dimensions of those characteristics. However those dimensions carry significant features for Narcissism, Machiavellianism and Psychopathy. In this framework main aim of this review paper was to discuss the similarities and the differences between three traits by addressing different dimensions. Moreover the scales which are used to measure those traits, and the relationship of three traits with the other personality models, coping styles and well-being were also summarized in this review paper. At last, suggestions were made related to the key factors that need to be studied in future research.
\end{abstract}

Keywords: Dark Triad, Narcissism, Machiavellianism, Psychopathy

Yazışma Adresi: Dr. Öğr. Üyesi Doruk Uysal Irak, Bahçeşehir Üniversitesi, İktisadi, İdari ve Sosyal Bilimler Fakültesi, Psikoloji Bölümü, Çrrağan cad. Osmanpaşa Mektebi sokak No:4 Beşiktaş / İstanbul.

E-posta: doruk.uysalirak@eas.bau.edu.tr

Gönderim Tarihi: 11.02.2019

Kabul Tarihi: 16.05.2019 
İnsanların kötü niyetli ve hatta acımasız taraflar1nı gözler önüne seren seri katillerin ya da diktatörlerin varlığından haberdar olsak bile, pek çoğumuz bu tür özellikler taşıyan insanlarla hayatımızda ender karşılaşırız. Diğer taraftan toplumda, bu insanlarla benzer kişilik özelliklerini, daha düşük seviyelerde gösteren kişiler de var olabilir ve bu kişiler toplum içinde dikkat çekmeden yaşamlarını sürdürebilirler. Bu kişiler zaman zaman işyerinde yüksek pozisyonlara dahi gelebilir ve yaşamları boyunca antisosyal davranışlar gösterseler bile herhangi bir ceza almadan ya da sorunla karşılaşmadan yaşamlarına devam etmeyi başarabilirler. Bu özelliklerdeki kişilerin tam olarak anlaşılması, biraz da Paulhus ve Williams (2002) adlı araştırmacıların "Karanlık Üçlü” kavramı üzerinde yaptıkları çalışmalarla olmuştur diyebiliriz. Karanlık Üçlü kavramı, Narsisizm, Makyavelizm ve Psikopati olmak üzere kötü niyetli özellikleri içeren ve bu nedenle de karanlık olarak adlandırılan üç kişilik özelliğinin bir araya gelmesiyle oluşmuştur. Bu kavramın ortaya atılması sonrasında özellikle son 20 yıldır "Karanlık Üçlü” kavramı araştırmacıların ilgisini çekmeye başlamıştır. Nitekim son olarak 2014 yılında Industrial and Organizational Psychology dergisinde "İşyerinde Sağlıklı olmayan Davranışlar” başlığı altında bu kişilik özelliklerinin önemine dikkat çekilmiştir. Bunun belki de en önemli nedeni Karanlık Üçlü kişilik özelliklerine sahip bireylerin çoğunlukla etik değerleri ve toplumsal kuralları yok sayarak, yalan, aldatma, hile, zorbalık gibi davranışları daha sık yapma eğiliminde olmalarıdır (Muris, Merckelbach, Otgaar ve Meijer, 2017).

$\mathrm{Bu}$ üç kişilik özelliğinin gelişmesinin hem genetik hem de çevresel faktörlerin etkisine bağlı olduğuna dair bulgular bulunmaktadır (Furnham, Richards ve Paulhus, 2013). Diğer bir ifadeyle, kötü niyetli kişilik özelliklerine sahip bireyler olumsuz çevresel koşullara maruz kaldıklarından bu şekilde davranmayı öğrenmiş olabilirler ya da öyle ortamlarda yaşamak zorunda olduklarından hayatlarını devam ettirmek amacıyla bu şekilde davranıyor olabilirler. Bu kişilik özelliklerinin kalıtım yoluyla bireyde var olması ve olumsuz çevresel koşulların ortaya çıkmasıyla bu özelliklerin tetiklenmesi de mümkündür. Diğer taraftan Karanlık Üçlü kişilik özelliklerine sahip bireyler çoğunlukla etkin olmayan baş etme yöntemleri kullanmaya daha eğilimli olurlar (örn; Birkás, Gács ve Csathó, 2016; Kealy, Ogrodniczuk, Rice ve Oliffe, 2017), bunun sonucunda stresli durumların olumsuz etkilerine çok daha fazla maruz kalabilirler ve psikolojik sağlıkları da daha olumsuz etkilenebilir.

$\mathrm{Bu}$ derleme makalede öncelikli olarak Karanlık Üçlü kavramı temel özellikleriyle ele alınacak ve bu kişilik özelliklerinin alt boyutları incelenecektir. Ayrıca bu bölümde Karanlık Üçlü'nün benzer ve farklı yanları tartışılacak ve başlıca kişilik modelleriyle olan ilişkileri de ele alınacaktır. Daha sonraki bölümlerde sırasıyla Karanlık Üçlü'nün ölçülmesinde kullanılan ölçüm araçları, kişilik özellikleriyle baş etme stilleri arasındaki ve iyi oluş hali arasındaki ilişkiler incelenecektir. Bu derleme makalenin temel amacı özellikle ülkemizde de son yıllarda pek çok araştırmada konu edilen (örn; Demircioğlu ve Köse, 2018; Erdoğan, 2018; Kircaburun, Demetrovics ve Tosuntaş, 2018; Özsoy, Rauthmann, Jonason ve Ardıç, 2017) bu üç kişilik özelliğinin daha ayrıntılı ele alınarak ulusal alanyazın için bir kaynak oluşturulmasını sağlamaktır.

\section{Karanlık Üçlü: Narsisizm, Makyavelizm ve Psikopati}

Karanlık Üçlü kavramı Narsisizm, Makyavelizm ve Psikopati olmak üzere kötü niyetli ya da kötücül olarak adlandırılan üç kișilik özelliğinden oluşur. Psikopati ve Narsisizm ilk olarak klinik psikoloji alanında çalışılmaya başlanmış olsa da (Jakobwitz ve Egan, 2006) sağlıklı nüfus içinde de Karanlık Üçlü'nün boyutları olarak ölçüldüklerinde "eşik altı (subclinical) kişilik özellikleri" olarak kabul edilirler (Aghababaei ve Błachnio, 2015). Narsisizm ve Psikopati klinik alanda kişilik bozukluğu olarak ele alındıklarında, Narsisistik Kişilik Bozukluğu ve Antisosyal Kişilik Bozukluğu olarak sınıflandırılırlar ve DSM-V'te belirtilen kriterleri karşılamaları gereklidir. Kişilik özellikleri ve kişilik bozuklukları arasındaki farkın temel olarak kişilik bozukluklarının daha katı ve değişmez olup kişiye yoğun sıkıntı vermesi ve işlevselliğini bozması olduğu söylenebilir. Kişilik özellikleri olarak Narsisizm ve Psikopati bu anlamda eşik altı say1lmaktadır (Furnham ve Crump, 2005). Makyavelizm ise bu iki kişilik özelliğinden farklı olarak temelde klinik anlamda bir kişilik bozukluğundan değil, Christie ve Geis (1970)'in çalışmalarına ilham kaynağı olan ünlü politikacı Nicolo Machiavelli'nin isminden gelmektedir.

$\mathrm{Bu}$ üç kişilik özelliğinden ilki, yani eşik altı Narsisizm, empati yoksunluğu, diğer insanların ihtiyaçlarına karşı kayıtsızlık ve üstünlük duygusu gibi özelliklerle tanımlandığı için, narsisist bireyler diğer insanlarla yakın ve içten ilişkiler kurmak yerine onların ilgi ve hayranlıklarını kazanmayı tercih etmektedirler (Sedikides ve Gregg, 2008). Benzer olarak, Emmons (1987) da narsisistik bireyleri sadece kendini düşünen ve insanları kendi çıkarları için manipüle etmekten çekinmeyen benmerkezci kişiler olarak tanımlamıştır. Diğer bir deyişle, narsisistler kendilerine aşırı derecede hayranlık duydukları ve sadece kendi başarılarının hayalini kurdukları için fazlasıyla ukala, kendileri dışındaki insanların duygu ve ihtiyaçlarını önemsemedikleri için de empati yoksunu olarak betimlenmektedirler (Fernie, Fung ve Nikčević, 2016). Narsisizm kavramı kendi büyüklüğü ve güzelliğine gereğinden fazla kendini kaptıran mitolojik figür Narcissus'tan gelmektedir ve bu kişilik özelliği de ta- 
nımlanırken mitolojik figürün özellikleri kullanılmıştır (Muris, Merckelbach, Otgaar ve Meijer, 2017).

İkinci Karanlık Üçlü kişilik özelliği olan Makyavelizm'e sahip bireyler kuşkucu bir bakış açısına sahip, etik değerleri önemsemeyen ve başarıya ulaşmak için manipülasyona başvurmanın gerekliliğine inanan insanlar olarak tanımlanmaktadırlar (Furnham, Richards ve Paulhus, 2013). Makyavelistlerin duygusal farkındalıklarının düşük olduğu ve açık olmadıkları, ayrıca duygu düzenleme konusunda zorluk yaşadıkları görülmüştür. $\mathrm{Bu}$ nedenle de, Makyavelistler amaçlarına ulaşmak için aldıkları kararlarda, bu kararın duygusal sonuçlarını değil uygulamadaki getirilerini hesaba katmayı tercih ederler (Zeigler-Hill ve Vonk, 2015). Makyavelistlerin bu özellikleri, Nicolo Machiavelli'nin krallara ve lordlara güçlerini ve kişisel çıkarlarını korumaları için önerdiği etik dış1 ve acımasız yöntemlerin günlük hayattaki yansımaları olarak görülebilir (Muris, Merckelbach, Otgaar ve Meijer, 2017).

Karanlık Üçlü kavramı içindeki son kişilik özelliği olan eşik altı Psikopati kişilik özelliğine sahip bireyler sapkın davranışlarda bulunmaya yatkın, düşük öz-kontrol ve düşük empati yeteneği olan, pişmanlık duygusundan yoksun, üstünlük arzusu olan, manipülatif ve yalanc1 insanlar olarak tanımlanmaktadırlar (Cleckley, 1976). Psikiyatri alanında kendisi de bir uzman olan Cleckley, bu olumsuz özellikleri s1k s1k yapay bir karizma maskesinin ardında gizleyen psikopatlar üzerinde sistematik gözlemler yaparak onların antisosyal eğilimlerini ve kontrolsüz davranışlarını ortaya çıkarmıştır. Psikopatisi yüksek insanlar genelde önceki deneyimlerden ders almazlar, güvenilmezdirler, benmerkezcil ve ikiyüzlü olurlar ve diğer insanları sevme kapasiteleri çok kısıtlıdır (Cleckley, 1976). Bu tanımlamalarda da görüldüğü üzere üç kişilik özelliği belirgin olarak farklı tanımlamalara sahiptir ancak araștırmacılar bu kișilik özellikleri arasındaki benzerliklere de vurgu yapmışlardır. Karanlık Üçlü kişilik özelliklerinin benzerliklerini ve farklılıklarını tartışmadan önce bu bölümde bu üç özelliğin boyutlarına ayrıntılı olarak değinilecektir.

\section{Karanlık Üçlü Kișilik Özelliklerinin Boyutları}

Karanlık Üçlü’yü oluşturan kişilik özellikleri çoğunlukla toplam puan olarak değerlendirilmiş ve bu nedenle özelliklerin alt boyutları ölçülmemiştir (bkz., Aghababaei ve Błachnio, 2015; Birkás, Gács ve Csathó, 2016; Noser, Zeigler-Hill ve Besser, 2014). Oysaki Karanlık Üçlü’yü oluşturan kişilik özelliklerinin her birinin kendine ait boyutları mevcuttur ve bu boyutlar farklı özelliklerle farklı şekillerde ilişki gösterebilirler (örn., Hill ve Roberts, 2012; Johnson, Beehr ve O’Brien, 2015). Alandaki çalışmalar incelendiğinde Karanlık Üçlü kişilik özelliklerinin, özellikle de Narsisizm (örn., Egan,
Chan ve Shorter, 2014; Zeigler-Hill ve Vonk, 2015) ve Psikopatinin (örn., Hare ve ark., 1990; Lee ve Salekin, 2010), faktör yapısını inceleyen ve Karanlık Üçlü araştırmalarında bu alt boyutların da dahil edilmesinin önemini vurgulayan az sayıda çalışma olduğu görülmektedir (örn., Furnham, Richards ve Paulhus, 2013; Rauthmann ve Kolar, 2012). Bu bölümde araştırmacıların bahsettiği Narsisizm, Makyavelizm ve Psikopati'nin alt boyutları daha ayrıntılı olarak ele alınacaktır.

Narsisizmin Alt Boyutları. Narsisizm kişilik özelliği ile ilgili çalışmalar incelendiğinde, bu özelliğin alt boyutlarının farklı şekillerde adlandırıldığ 1 görülmektedir; ancak özellikle iki çalıșma araştırmacılar tarafından daha fazla desteklenmektedir. Bunlardan ilki Ackerman ve arkadaşlarının (2011) Narsisizmin "Liderlik/Otorite (Leadership/Authority)", "Grandiyöz Gösterişçilik (Grandiose Exhibitionism)" ve "Hak İddia Etme/Sömürücülük (Entitlement/Exploitativeness)" olmak üzere 3 boyutlu olduğu yönündeki çalışmalarıdır. Liderlik/Otorite boyutu Narsisizmin en ișlevsel olan boyutudur. Bunun temel nedeni bu boyutun uyumluluk kavramiyla negatif ilişkiye sahip olmasına rağmen nevrotiklik ve antisosyal davranışlarla ilişkisinin olmamasıdır (Ackerman ve ark., 2011). Buna ek olarak bu boyut, sosyal yetkinlik, dişadönüklük, özsaygı ve hedefte kararlılık gibi kavramlarla pozitif ilişkiye sahiptir. Diğer taraftan, Hak İddia Etme/ Sömürücülük boyutu, antisosyal davranışlar, nevrotiklik, üniversiteye uyum sağlama ve ilişki kurma gibi yetişkinliğe özgü rollerde başarısız olma ile pozitif ilişkili olduğu için Narsisizmin işlevsel olmayan yönü olarak kabul edilmektedir. Grandiyöz Gösterişçilik boyutunun ise hem özsaygı ve dışadönüklük gibi olumlu kavramlarla hem de Makyavelizm ve zarar verici davranışlar gibi olumsuz kavramlarla ilişkisi olduğu ve bu nedenle işlevsellik bakımından ortada yer alan bir boyut olduğu söylenebilir (Ackerman ve ark., 2011).

Yapılan bir çalışmada Hak İddia Etme/Sömürücülük boyutu ile yaşam doyumu arasında negatif ilişki olduğu, Narsisizmin diğer iki boyutunun ise yaşam doyumu ile pozitif ilişkilerinin olduğu bulunmuştur (bkz., Hill ve Roberts, 2012). Hill ve Roberts (2012) elde ettikleri bu pozitif ilişkinin Grandiyöz Gösterişçilik boyutuna kıyasla Liderlik/Otorite boyutu için çok daha güçlü olduğunu göstererek bu boyutların işlevsel olduğu görüşünü desteklemişlerdir. Bunun yanısıra, Buelow ve Brunell (2014) Hak İddia Etme/Sömürücülük boyutunun risk alma ile ilgili olan finansal ve etik davranışları yordadığını bulmuşlardır. Araştırmacılar, elde edilen bu sonucu Narsisizmin bu boyutundan (Hak İddia Etme/Sömürücülük) yüksek puan alan bireylerin diğer insanlara zarar vereceklerini düşünmeden, sadece kişisel amaçlarına ulaşmak için insanları kullanmalarına ve bunu yapar- 
ken de riskli davranışlar göstermelerine bağlamışlardır. Buna ek olarak, yine Hak İddia Etme/Sömürücülük boyutunun özelliklerini taşıyan Narsisistlerin, uzun sürede yüksek miktarda kazanç elde etmektense kısa sürede düşük miktarda kazanç elde etmeyi tercih ettikleri görülmüştür. Grandiyöz Gösterişçilik boyutunun ise madde kullanımını, saldırgan ve riskli davranışları yordad1ğ1 bulunmuştur. Kendilerini üstün gören Narsisistlerin, olası tehditleri küçümsemeleri ve kendilerine bir zarar gelmeyeceğini düşünmelerinden dolayı riskli davranışlarda bulunmaktan çekinmemeleri bu ilişkiyi açıklayabilir (Buelow ve Brunell, 2014).

Benzer şekilde Zeigler-Hill ve Vonk (2015), Narsisizmin Hak İddia Etme/Sömürücülük boyutunda yüksek puan alanların, dürtü kontrolü ve duygu düzenlemede zorluklar yaşadıklarını göstermișlerdir. Bu durumun nedenlerinden biri bu özellikleri taşıyan Narsisistlerin özel ilgi görme beklentileri ve arzu ettiklerine hemen ulaşma istekleri olabilir. Diğer taraftan, Narsisizmin Liderlik/ Otorite ve Grandiyöz Gösterişçilik boyutlarında duygu düzenlemeyle ilgili bir problem yaşanmadığı bulunmuştur (Zeigler-Hill ve Vonk, 2015). Clarke, Karlov ve Neale (2015) Narsisistik bireylerin düşük öz-saygılarını kendini üstün görme ve kibirli davranış ile kapatmaya çalıştıklarını belirtmişlerdir. Araştırmacılar bu durumu Narsisizmin işlevsel olmayan yönü olarak değerlendirmişlerdir ve depresyon, stres gibi sonuçlarla ilişkilendirmişlerdir. Narsisizmin daha işlevsel olan ve özellikle Liderlik/ Otorite boyutunda daha belirgin olarak görülen yüksek özgüven, düşük nevrotiklik, liderlik rolüne duyulan arzu gibi yönlerinin ise stres, kaygı ve depresyonla ilişkisi olmadığı belirlenmiştir (Clarke, Karlov ve Neale, 2015).

Narsisizmin bir diğer yaygın olarak kullanılan modeline göre, Narsisizm "Grandiyöz (Grandiose)" ve "Kırılgan (Vulnerable)" olmak üzere iki farklı boyuttan oluşmaktadır. Giacomin ve Jordan (2016) Grandiyöz Narsisizmi kibirli, dışadönük, sömürücü olarak tanımlarken, Kırılgan Narsisizmi hassas, içedönük ve nevrotik olarak tanımlamışlardır. Egan, Chan ve Shorter (2014) Grandiyöz Narsisistlerin daha dışadönük olduklarını, yaşam memnuniyetleri ve mutluluk seviyelerinin daha yüksek olduğunu, Kırılgan Narsisistlerin ise daha uyumsuz olduklarını, duygularının daha değişken olduğunu ve Makyavelizm ile Psikopati özelliklerine daha fazla sahip olduklarını belirtmişlerdir. Buna paralel olarak, Rose (2002) Grandiyöz Narsisizmin öz-sayg1 ve mutlulukla pozitif bir ilişkiye sahip olduğunu, Kırılgan Narsisizmin ise her ikisiyle de negatif ilişkiye sahip olduğunu belirtmiştir. Ayrıca özsaygının narsisizmin iki boyutu ve mutluluk arasındaki ilişkilerde açıklayıcı bir faktör olduğu belirlenmiştir. Diğer bir deyişle Grandiyöz Narsisistler yüksek özsaygıya sahip oldukları için daha mutlu olurken, Kırılgan Narsisistler özsaygılarının düşük olmasına bağlı olarak daha mutsuz olurlar (Rose, 2002). Ancak Grandiyöz Narsisistler riskli davranışlarda bulunmaya, madde ve alkol kullanmaya daha eğilimli olmaktadırlar (Buelow ve Brunell, 2014).

Makyavelizmin Alt Boyutları. Alanyazındaki tüm bulgular Narsisizmin ve Psikopatinin çok boyutlu yapıs1nı ve bu boyutların Karanlık Üçlü ile ilgili yapılan araştırmalarda ele alınmasının önemini desteklese de, Makyavelizm'in boyutlarını inceleyen çalışma sayısı oldukça kısıtlı kalmaktadır. Aslen, Makyavelizm kavramı Christie ve Geis (1970) tarafından üç boyutlu olacak şekilde kavramsallaştırılmış olup "Manipülatif Taktikler (Manipulative Tactics)", "Insan Doğasına Alaycı Baklş (Cynical View of Human Nature)" ve "Geleneksel Ahlaki Değerleri Yoksayma (Disregard for Conventional Morality)" boyutlarından oluştuğu düşünülmüştür. Makyavelizmin faktör yapısını incelemiş olan nadir çalışmalardan birinde, Makyavelizmin "Taktikler (Tactics)" ve "Görüşler (Views)" olmak üzere iki boyuttan oluştuğu tespit edilmiştir (Monaghan, Bizumic ve Sellbom, 2016). Corral ve Calvete (2000) yaptıkları çalıșmada "Pozitif Kişilerarası Taktikler (Positive Interpersonal Tactics)", "Negatif Taktikler (Negative Tactics)", "İnsan Doğasına Pozitif Bakış (Positive View of Human Nature)" ve "Insan Doğasina Alaycı Bakış (Cynical View of Human Nature)" olmak üzere dört boyut üzerinde durmuşlardır. Sonuç olarak, tüm bu çalışmalar Makyavelizmin faktör yapısı konusundaki belirsizliği ortadan kaldırmak için daha fazla araştırma yapılmasına gerek duyulduğunu göstermektedir.

Psikopatinin Alt Boyutları. Psikopati için kullanılan en yaygın ayrım, Berg ve arkadaşları (2013) tarafından ortaya atılmış olan "Birincil (Primary)" ve "İkincil (Secondary)" boyutlarıdır. Birincil Psikopatide bireyler korkusuz ve duygu düzenlemede daha başarılıyken, İkincil Psikopatide bireylerin daha dürtüsel, kayg1l ve saldırgan davranmaya eğilimli oldukları belirlenmiştir (Berg ve ark., 2013). İkincil Psikopatide yüksek düzeyde dürtüsellik, kaygı ve endişe görülürken, Birincil Psikopatide çoğunlukla kandırma, manipülasyon ve soğukkanlılık gibi kişilerarası ve duygulanım özellikleri ortaya çıkmaktadır (Lee ve Salekin, 2010). ). Kavramsal olarak, Birincil Psikopati'nin bencil, soğukkanlı olma ve diğer insanları çıkarları için kullanmaktan pişmanlık duymama gibi özellikleri içerdiği, İkincil Psikopati’nin ise daha çok antisosyal ve sapkın davranışları kapsadığı söylenebilir (Hare ve ark., 1990).

Yapılan çalışmalar İkincil Psikopatinin yüksek olması durumunda bu bireylerin işyerinde gerginliği arttırdığını ve ilişkileri bozduğunu göstermiştir (Johnson, Beehr ve O'Brien, 2015). Araştırmacılar bunun nedenini bireylerin duygusal olarak çok değişken olmalarına ve isyankar davranışlarda bulunmaları sonucunda hem duygusal hem de davranışsal olarak stres yaratan durumlara 
açık hale gelmelerine bağlamışlardır. İkincil Psikopatiyle karşılaştırıldığında, Birincil Psikopatisi yüksek olan bireyler, nevrotiklik düzeylerinin düşük olmasina bağlı olarak, stresli durumlar karşısında o kadar hassas olmazlar. Bu nedenle Birincil Psikopati İkincile göre daha işlevsel olarak kabul edilmektedir (Johnson, Beehr ve O'Brien, 2015). Karpman (1941) Birincil Psikopatinin genetik temeli olduğunu ve bu davranışların altında yatan kalıtsal bir duygusal eksiklik olabileceğini savunmuştur. Birincil Psikopatisi yüksek olan bireylerin duygusal farkındalık ve net olmada (emotional awareness and clarity) eksikliklerinin olduğunu gösteren bir araştırma da bu görüşü destekler niteliktedir (Zeigler-Hill ve Vonk, 2015). Diğer taraftan İkincil Psikopatide görülen dürtüsel ve antisosyal davranışların nedeni olarak travmatik deneyimler, yetersiz ebeveynlik veya kisitl sosyoekonomik durumlar gibi olumsuz çevresel koşullar görülmüştür (Karpman, 1941). Sonuç olarak Birincil Psikopatide kalitsal özellikler, İkincil Psikopatide ise çevresel özelliklerin etkisinden bahsedilebilir.

Yaygın olarak kullanılan diğer bir psikopati modeli ise "Kişilerarası (Interpersonal)", "Duygulanım (Affective)", "Yaşam Biçimi (Lifestyle)" ve "Antisosyal (Antisocial)" olmak üzere psikopatinin 4 farklı boyutundan bahsetmektedir (Hare ve Neumann, 2008). Kişilerarası boyuttan yüksek puan alan bireyler için çoğunlukla yanıltıcı, manipülatif, yüksek kendilik değerine sahip ve yapay bir çekiciliğe sahip olma gibi özelliklerden bahsedilirken; Duygulanım boyutundan yüksek alanlar için zayıf empati, davranışları sonucunda pişmanlık ya da sorumluluk duymama gibi özellikler ön plana çıkmaktadır. Yaşam Biçimi boyutunda çoğunlukla uzun vadeli amaçlar edinmekten kaçınan, sorumsuz ve dürtüsel davranma eğilimi olan bireyler yer almaktadır. Bu boyuttan yüksek puan alan kişiler çabuk sıkılabilir ve bu sıkıntıyı gidermek için yüksek derecede uyarana ihtiyaç duyabilirler (Hare ve Neumann, 2008). Son boyut olan Antisosyal boyutunda ise kişinin erken yaşlardan itibaren davranış sorunlarının olması, suça yatkınlık ve kendi davranışlarını kontrol etmede zorlanma görülmektedir. Bu dört boyuta bakıldığında, Kişilerarası ve Duygulanım boyutlarının büyük ölçüde Birincil Psikopatiye, Yaşam Biçimi ve Antisosyal boyutlarının ise İkincil Psikopatiye benzediği görülmektedir (Hare ve Neumann, 2008). Tablo 1'de Karanlık Üçlü olarak ele aldığımız Narsisizm, Makyavelizm ve Psikopati'nin alt boyutlarına ilişkin yaklaşımlar bir arada özetlenmiştir.

\section{Karanlık Üçlü Kişilik Özelliklerinin Benzer ve Farkıı Yönleri}

Narsisizm, Makyavelizm ve Psikopati kişilik özelliklerinin üçü de sosyal hayatta kötü niyetli olarak tanımlanabilecek özelliklere sahiptirler. Bu üç kişilik özelliği pek çok ortak noktaya sahip oldukları için Karanlık Üçlü adı verilerek daha kapsayıcı olduğu düşünülen bir ismin altında toplanmışlardır. Ne var ki araştırmacılar, bu ortak noktaların ne olduğu konusunda tam da fikir birliğine varamamışlardır. Jones ve Paulhus'a (2011) göre Karanlık Üçlü'nün ortak noktaları "hissizlik (callousness)" ve "manipülatiflik" özellikleridir. Araştırmacılar bu özellikleri belirlerken her üç kişilik özelliğinin de sahip olduğu iki temel davranışın altını çizmişlerdir; insanların acı çekmesi karşısında kayıtsız kalmaları ve insanları kendi çıkarları uğruna kullanmaktan çekinmemeleri. Diğer taraftan Jakobwitz ve Egan (2006) bu kişilik özelliklerine sahip insanların işbirlikçi olmamaları, güvenilmez ve düşüncesiz olmaları nedeniyle "düşük uyumluluk (agreeableness)" ve "düşük özdisiplin (conscientiousness)" özelliklerini Karanlık Üçlü’nün ortak özellikleri olarak ifade etmişlerdir. "Dürüstlüğün ve alçakgönüllülüğün (honesty-humility) düşük olması" Lee ve Ashton (2005) tarafından önerilen bir diğer ortak özellik olmuştur. Nitekim araştırmacılara göre Karanlık Üçlü kişilik özelliklerine sahip bireyler, samimiyetsiz ve ukala olup amaçları için adil olmayan yollara başvurmaya eğilimlidirler. Lynam ve Derefinko (2005), insan ilişkilerinde düşmanca tavır takınma anlamına gelen "kişilerarası uzlaşmazlık (interpersonal antagonism)" kavramının Karanlık Üçlü’nün ortak özelliği olabileceğini vurgulamışlardır. Diğer taraftan Jonason, Li, Webster ve Schmitt (2009) "sosyal istismarcilık (social exploitativeness)" özelliğinin Karanlık Üçlü’yü birleştiren bir özellik olacağını, çünkü üç kişilik özelliğinde de bireylerin istediklerini elde etmek için diğer insanlardan faydalanma davranışı gösterdiklerini belirtmişlerdir.

Karanlık Üçlü'nün ortak özelliğinin ne olabileceğine dair çeşitli öneriler getiren araştırmacıların yanı sıra bazı araştırmacılar bu üç kişilik özelliğinin aslında birbirinden ayırt edilemeyecek kadar çok ortak noktası olduğunu iddia etmişlerdir. Diğer bir deyişle, Karanlık Üçlü'nün ayrı ayrı ölçmeye gerek olmayacak kadar benzer üç kişilik özelliğinden oluştuğunu savunmuşlardır. Bu bağlamda, Paulhus ve Williams (2002) yaptıkları çalışmada bu üç kişilik özelliğinin birbirlerinden yeterince farklı olup olmadığını araştırmışlardır. Bu düşüncenin test edilebilmesi için de Karanlık Üçlü ile Beş Faktör Modeli (the Five Factor Model) (Costa, McCrae ve Dye, 1991) içindeki kişilik özellikleri arasındaki ilişkileri incelemişlerdir. $\mathrm{Bu}$ analizler sonucunda sadece uyumluluğun her üç kişilik özelliğiyle anlamlı negatif bir ilişkisi olduğu görülmüștür. Elde edilen sonuçlar diğer tüm benzerliklerin Karanlık Üçlü grubundan sadece iki kişilik özelliği için geçerli olduğu şeklindedir. Örneğin, Narsisizm ve Psikopati dışadönüklük ve deneyime açıklik (openness to experience) ile ilişkiyken, Psikopati ve Makyavelizm özdisiplin ile negatif ilişkili bulunmuştur. 
Tablo 1. Karanlık Üçlü Kişilik Özelliklerinin Alt Boyutları

\begin{tabular}{|c|c|c|}
\hline \multicolumn{3}{|c|}{ Narsisizm } \\
\hline Liderlik/Otorite & \multicolumn{2}{|c|}{ Grandiyöz } \\
\hline Grandiyöz Gösterişçilik & \multirow{2}{*}{\multicolumn{2}{|c|}{ Kirılgan }} \\
\hline Hak İddia Etme/Sömürücülük & & \\
\hline \multicolumn{3}{|c|}{ Makyavelizm } \\
\hline Manipülatif Taktikler & \multirow{2}{*}{ Taktikler } & Pozitif Kişilerarası Taktikler \\
\hline İnsan Doğasına Alaycı Bakış & & Negatif Taktikler \\
\hline \multirow{2}{*}{ Geleneksel Ahlaki Değerleri Yoksayma } & \multirow{2}{*}{ Görüşler } & İnsan Doğasına Pozitif Bakış \\
\hline & & İnsan Doğasına Alaycı Bakış \\
\hline \multicolumn{3}{|c|}{ Psikopati } \\
\hline \multirow{2}{*}{ Birincil } & \multicolumn{2}{|c|}{ Kişilerarası } \\
\hline & \multicolumn{2}{|c|}{ Duygulanım } \\
\hline \multirow{2}{*}{ İkincil } & \multicolumn{2}{|c|}{ Yaşam Biçimi } \\
\hline & \multicolumn{2}{|c|}{ Antisosyal } \\
\hline
\end{tabular}

Bunlara ek olarak sadece Psikopatinin düșük nevrotiklik ile ilişkili olduğu bulunmuştur (Paulhus ve Williams, 2002). Kişilik modelleri bağlamındaki tüm bu bulgular da Narsisizm, Makyavelizm, ve Psikopatinin birbirlerinden ayırt edilebilecek kadar farklı kavramlar olduklarını destekler niteliktedir.

Karanlık Üçlü’yü oluşturan kişilik özelliklerini birbirinden farklı yapan diğer bir nokta ise her bir özelliğin "karanlık olma" derecesidir. Eğer bir doğru üzerinde yer aldıkları düşünülürse, Psikopatinin en karanlık uçta, Narsisizmin en aydınlık uçta, Makyavelizm' in ise ikisinin arasında yer aldığı söylenebilir (Rauthmann ve Kolar, 2012). Muris, Merckelbach, Otgaar ve Meijer (2017) her üç kişilik özelliğinin de saldırganlık/suça yatkınlık, tutarsız davranışlar, cinsellikle ilgili problemler, duygusal yoksunluk, olumsuz sağlık durumu, kişilerarası ilişkilerde zorlanma, etik problemler ve antisosyal stratejiler gibi olumsuz psikososyal sonuçlarla ilişkileri olduğunu bulmuşlardır. Bulunan bu ilişkilerin gücü Psikopatide en yüksek, Narsisizmde en düşük ve Makyavelizmde diğer iki özelliğin arasında bulunmuştur. Buna paralel olarak, Paulhus ve Williams (2002) da Psikopatların uyumluluk ve kayg1 seviyelerinin düşük olması göz önüne alınd1ğında üç kişilik özelliği arasındaki en tehlikeli özellik olduğunu belirtmişlerdir. Özellikle uyumluluk ve kaygının düşük olmasının bu bireyleri sapkın davranışlarda bulunmaya daha eğilimli hale getirdiğini savunmuşlardır.
Bu sebeple, Narsisizm ve Makyavelizme kıyasla Psikopatinin ilişkisel anlamda işlevsel olan yönlerini bulmak daha zordur. Yine de, Psikopatisi yüksek bireylerin kendileriyle ilgili olumlu görüşleri ve düşük kaygı seviyeleri kendilerini mutlu hissetmelerini sağlayabilir (Paulhus ve Williams, 2002). Makyavelizm ve Narsisizm, Psikopatiye göre daha işlevsel ve daha az karanlık kişilik özellikleri olsalar da, araştırmacılar her üç kişilik özelliğinin de olumsuz davranışsal sonuçlarının olumlu olanları geride bıraktığını vurgulamışlardır (Paulhus ve Williams, 2002; Rauthmann ve Kolar, 2012).

Karanlık Üçlü kişilik özelliklerinin diğer bazı kavramlarla olan ilișkilerinin farklı olması da bu üç özelliğin birbirinden farklı olduğuna dair bir göstergedir. Örneğin; Christie ve Geis (1970) Narsisizmin çoğunlukla kendini-yüceltme (self-enhancement) davranışlarında görülen bir kişilik özelliği olduğunu ve Psikopatinin daha sonra geldiğini belirtmişlerdir. Buna karşın, Makyavelizmin kendini-yüceltme ile ilişkisi bulunmamıştır ve bu bulgu Makyavelistlerin kendilerini değerlendirirken daha gerçekçi davrandıkları şeklinde yorumlanmıştır (Christie ve Geis, 1970).

Diğer taraftan Narsisizmin zeka ile düşük de olsa pozitif ilişkisi olduğu görülmüştür. Makyavelizm ve Psikopatinin ise sözel zekaya oranla sözel olmayan zeka ile daha güçlü bir ilişkisi olduğu bulunmuştur (Paulhus ve Williams, 2002). Araştırmacılar bu bulgu için iki farklı açıklama getirmişlerdir. Bunlardan ilki, Makyavelizm 
ve Psikopatinin yüksek olduğu bireylerin fikirlerini aktarırken yaşadıkları zorluklar nedeniyle daha kötü niyetli kişilerarası yöntemler kullanmayı tercih ediyor olabilecekleridir. Diğer bir açıklamaya göre ise bu özelliklere sahip bireylerin nörolojik bir sorun yaşıyor olabilecekleridir (Paulhus ve Williams, 2002). Tüm bunların yanısıra Makyavelistler ve Psikopatların, Narsisistlere göre duygu durumlarının daha olumsuz seyrettiği bulunmuştur (Egan, Chan ve Shorter, 2014).

Bütün bu bulgulara paralel olarak, Furnham, Richards ve Paulhus (2013) Karanlık Üçlü kişilik özellikleri arasında pozitif ilişkiler olsa da ve birbirleriyle birçok ortak noktaya sahip olsalar da, birbirlerinden ayırt edilebilecek kadar farklı yönlerinin olduğunu savunmuşlardır. Sonuç olarak, Karanlık Üçlü’yü oluşturan kişilik özelliklerinin hepsi olumsuz özellikler olsalar da ve birbirleriyle pek çok ortak yönleri olsa da, tamamen aynı olmadıkları için ayrı ayrı ölçmek gerekmektedir. Bu konu daha sonraki bölümde ele alınacaktır; ancak daha önce üç kişilik özelliğin başlıca kişilik modelleriyle olan ilişkilerinden bahsedilecektir.

\section{Karanlık Üçlü’nün Başlıca Kişilik Modelleriyle Olan İlişkileri}

Karanlık Üçlü kişilik özelliklerinin başlıca kişilik modelleriyle ilişkili olduğu bulunmuştur. $\mathrm{Bu}$ modeller içinde en popüler olanlardan Beş Faktör Modeli, Dışadönüklük, Uyumluluk, Özdisiplin, Deneyime Açıklık ve Nevrotiklik olmak üzere beş boyuttan oluşmaktadır (Costa, McCrae ve Dye, 1991). Muris, Merckelbach, Otgaar ve Meijer (2017) Karanlık Üçlü’yü oluşturan kişilik özellikleriyle Uyumluluk boyutu arasında negatif bir ilişki olduğunu ve bu ilişkinin Makyavelizm $(r=-.43)$ ve Psikopati $(r=.46)$ için Narsisizm'e göre $(r=-.21)$ daha güçlü olduğunu belirtmişlerdir. Bu da Narsisizmin diğer iki kişilik özelliğine göre daha "az karanlık" tarafta yer aldığını doğrular niteliktedir. Diğer bir deyişle, Narsisizm sosyal anlamda itici bir özellik olmasına rağmen, Narsisistlerin, Makyavelist ve Psikopatlara göre sıcak ve dostça ilişkiler kurması daha olası görünmektedir.

Bunun yanısıra, Narsisizmin Deneyime Açıklık ve Dışadönüklük boyutlarıyla da pozitif ilişkiye sahip olduğu görülmüştür (Hudek-Knežević, Kardum ve Mehić, 2016). Bu bulgu da yine Narsisistlerin sosyal ilişkilerinde diğer iki Karanlık Üçlü kişilik özelliğine göre daha başarılı olduğunu desteklemektedir. Psikopatların sapkın davranışlarda bulunmaya yatkınlıklarını doğrulayan yönde bir bulgu da Özdisiplin ile olan negatif ilişkide görülmektedir (Muris, Merckelbach, Otgaar ve Meijer, 2017). Bu bulgu Psikopati boyutunda yüksek olan bireylerin, kendi davranışlarını kontrol etme becerilerinin ve disiplinlerinin düşük olması ve dürtüsel davranışları düşünüldüğünde daha da anlam kazanmaktadır. Benzer ola- rak, Makyavelizmin Özdisiplin boyutuyla negatif ilişkisi olduğu bulunmuş olsa da (Muris, Merckelbach, Otgaar ve Meijer, 2017), bu ilişki Makyavelistlerin hedef odaklı ve disiplinli hareketleri düşünüldügüünde beklenmeyen bir bulgu olarak göze çarpmaktadır. Ancak araştırmacılar bu bulgunun Makyavelistlerin etik kuralları yok sayması ile ilişkili olabileceği şeklinde yorumlamışlardır (Muris, Merckelbach, Otgaar ve Meijer, 2017).

Karanlık Üçlü'nün aynı zamanda Beş Faktör Modeli'ndeki 5 temel boyutun alt boyutlarında da birbirlerinden ayrıldıkları görülmüştür (Furnham, Richards ve Paulhus, 2013). Örneğin, Uyumluluk ana boyutunun alt boyutları olan alçakgönüllülük (modesty) ve açık sözlülük (straightforwardness) ile en güçlü ilişkisi olan Narsisizmdir. Alçakgönüllülüğün düşük olması Narsisistlerin kendilerini çok fazla yücelttiklerini ve ilgi odağı olmaktan çok hoşlandıklarını gösterirken, açık sözlülüğün düşük olması diğer insanları kandırmaktan ve manipüle etmekten çekinmedikleri anlamına gelmektedir (Costa, McCrae ve Dye, 1991). Diğer yandan, Özdisiplin ana boyutunun alt boyutları olan tedbirli olma (deliberation) ve görev bilinci (dutifulness) en çok Psikopati ile ilişkili bulunmuştur (Furnham, Richards ve Paulhus, 2013). Tedbirliliğin düşük olması Psikopatisi yüksek bireylerin, davranışlarının sonuçlarını düşünmeden dürtüsel bir şekilde hareket etmeleri, görev bilincinin düşük olması ise toplumsal kuralları ve yasaları çiğneme eğiliminde oldukları anlamına gelmektedir (Costa, McCrae ve Dye, 1991).

Karanlık Üçlü ile diğer bir kişilik modeli olan Hexaco Kişilik Modeli (Lee ve Ashton, 2005) arasında da anlamlı ilișkiler olduğunu gösteren çalışmalara rastlanmiştır (örn; Hudek-Knežević, Kardum ve Mehić, 2016; Muris, Merckelbach, Otgaar ve Meijer, 2017). Hexaco Modeli, Dışadönüklük, Deneyime Açıklık, Uyumluluk, Özdisiplin, Duygusallık ve Dürüstlük-Alçakgönüllülük olmak üzere 6 boyuttan oluşmaktadır. Karanlık Üçlü Dürüstlük-Alçakgönüllülük boyutuyla negatif ilişkilidir (bkz., Hudek-Knežević, Kardum ve Mehić, 2016). Diğer bir deyişle Karanlık Üçlü kişilik özelliklerinin varlığı durumunda yalan söyleme, haksızlık yapma, aldatma ve güvenilmez olma gibi davranışlara eğilimli olma durumu artmaktadır. Yine burada da, Narsisizmin diğer iki kişilik özelliğine göre daha "az karanlık" tarafta yer aldığ 1 söylenebilir. Bu düşüncenin temel nedeni Dürüstlük-Alçakgönüllülük ile olan negatif ilişkinin Makyavelizm ve Psikopati için daha güçlü olmasıdır (Muris, Merckelbach, Otgaar ve Meijer, 2017).

Karanlık Üçlü ile Dürüstlük-Alçakgönüllülük ana boyutunun alt boyutlarının da birbirlerinden farklı ilişkileri olduğu görülmüştür. Örneğin, Makyavelizm ve Psikopati içtenlik (sincerity) ve adillik (fairness) alt boyutlarıyla güçlü ve negatif ilișkilidir (Muris, Merckelbach, Otgaar ve Meijer, 2017). İçtenlik alt boyutundan düşük 
puan alınması kişinin samimi olmadığı ve kişisel çıkarları için insanları manipüle ettiği anlamına gelirken, düşük adillik puanı kişinin amaçlarına ulaşmak uğruna insanları kandırmaktan geri kalmaması anlamına gelmektedir (Lee ve Ashton, 2005). Diğer yandan, Narsisistik yönleri ağır basan bireylerin alçakgönüllülük (modesty) alt boyutunda oldukça düşük puanlar aldıkları görülmüştür (Muris, Merckelbach, Otgaar ve Meijer, 2017). Bu da Narsisistlerin kendilerini diğer insanlardan üstün görme eğiliminde olmaları ve diğerlerinden ayrıcalık görmeleri gerektiğine inanmaları anlamına gelmektedir (Lee ve Ashton, 2005). Diğer bir ifadeyle, Makyavelizm ve Psikopatinin daha ağırlıklı olarak yalancılık ve karşısındakini kandırma ile ilişkisi varken, Narsisizmin daha çok kibir ile ilgili olduğu söylenebilir (Muris, Merckelbach, Otgaar ve Meijer, 2017).

Kişilikle ilgili diğer önemli bir model olan Kişilerarası Döngüsel Model (Interpersonal Circumplex) (Wiggins, 1979), Yetkinlik (Agency) ve Sevecenlik (Communion) olmak üzere iki eksenden oluşmaktadır. Yetkinlik ekseni, otonomi ve üstünlük elde etmek için mücadele etmeyi temsil ederken, sevecenlik ekseni diğer insanlarla bağlantı kurma ve insanlara yardım etme isteği ile tanımlanmaktadır (Wiggins, 1979). Jones ve Paulhus (2011) Karanlık Üçlü’nün yüksek yetkinlik ve düşük sevecenlik eksenlerinde yer aldığını göstermiştir. Buna göre Karanlık Üçlü kişilik özelliklerine sahip bireylerin, bağımsız olma ve üstünlük kurma yönleri ağır basarken, diğer insanlarla ilişki kurma veya onlara yardımcı olma gibi bir çabalarının olmadığg vurgulanmıştır. Ayrıca Psikopati, dürtüsellik (impulsivity) boyutuyla daha güçlü bir ilişki içindeyken, Narsisizm daha çok üstün benlik/ kendini-yüceltme (superior identity/self-enhancement) boyutunda kendini göstermektedir (Jones ve Paulhus, 2011). Diğer bir deyişle, Psikopati puanı yüksek olan bireyler, dürtüsel davrandıkları için kendi davranışları üzerinde düşük kontrol becerisine sahipken, yüksek derecede Narsisist bireyler, abartılı düzeyde olumlu kendilik algılarıyla ayırt edilebilmektedirler.

Tüm bu bulgulara baktığımızda, Karanlık Üçlü kişilik özelliklerinin yaygın olarak kullanılan kişilik modelleriyle olan ilişkilerinde de birbirlerinden farkl1lık gösterdikleri görülmektedir. Burada unutulmaması gereken önemli bir nokta, Karanlık Üçlü'yü oluşturan kişilik özelliklerinin, Beş Faktör Modeli (Costa, McCrae ve Dye, 1991), Hexaco Kişilik Modeli (Lee ve Ashton, 2005) ve Kişilerarası Döngüsel Modeli (Wiggins, 1979) oluşturan ana boyutlarla ortak ilişkilerinin olduğu, ancak bu ana boyutların altında yer alan alt boyutlarla olan ilişkilerinde birbirlerinden farklılık gösterdikleri gerçeğidir. $\mathrm{Bu}$ durumu daha ayrıntılı ifade etmek gerekirse, Karanlık Üçlü'nün sırasıyla Uyumluluk (Costa, McCrae ve Dye, 1991) ile negatif, Dürüstlük-Alçakgönüllülük (Lee ve Ashton, 2005) ile negatif, Yetkinlik ile pozitif ve Sevecenlik (Wiggins, 1979) temel boyutları ile negatif ilişkileri olduğu, ancak bu temel boyutların alt boyutlarında Narsisizm, Makyavelizm ve Psikopatinin birbirinden farklılaştığ 1 bulunmuştur. Aslında, bu durum bir önceki bölümde tartışılan Karanlık Üçlü'nün benzer ve farklı yönleri konusuna ek olarak Karanlık Üçlü kişilik özelliklerinin bir kavram altında toplanabilecek kadar benzer, ama aynı zamanda da ayrı ayrı ölçmeyi gerektirecek kadar birbirlerinden farklı olduklarını desteklemektedir. Yani bu özellikleri tek bir isim altında topluyor olsak da ölçümlerinin ayrı ayrı yapılması önemli görünmektedir.

\section{Karanlık Üçlü Kişilik Özelliklerinin Ölçümünde Kullanılan Ölçüm Araçları}

Karanlık Üçlü kişilik özellikleriyle ilgili olarak yapılan çalışmalarda ele alınması gereken diğer bir konu da bu kişilik özelliklerinin nasıl ölçüldüğü sorusudur. Bu sorunun en temel nedeni, alanyazında farklı fikirlerin olmasıdır. Üç kişilik özelliğini ele alan çalışmalar incelendiğinde, kişilik özelliklerinin ölçümünde kullanılan ölçme araçları için iki ayrı seçenek bulunduğu görülmektedir. Bunlardan ilki, bu üç özelliği birlikte, aynı anda ölçerek bireyin bu kişilik özelliklerini ne kadar taşıdığını gösteren ölçeklerdir (örn; Jonason ve Webster, 2010; Jones ve Paulhus, 2014); ikincisi ise bu üç kişiliği ayrı ayrı ölçen ölçüm araçlarıdır (örn; Christie ve Geis, 1970; Paulhus, Neumann ve Hare, 2009; Raskin ve Hall, 1979).

Karanlık Üçlü tek bir ölçekle ölçülmek istendiğinde, iki farklı ölçek alanyazında sıklıkla tercih edilmiştir. Bunlardan biri, Jonason ve Webster tarafindan 2010 y1lında geliştirilmiş olan Kirli Düzine'dir (Dirty Dozen). Adından da anlaşılacağı gibi, 12 maddeden oluşan bu ölçek her bir kişilik özelliği için 4 maddeden oluşmaktadır. $\mathrm{Bu}$ ölçeğin geçerlik ve güvenirliğine dair bazı şüpheler bulunmaktadır; çünkü ölçeğin psikometrik özelliklerini inceleyen çalışmalarda bir kısım araştırmacı ölçeğin güvenirliğini yeterli bulup ölçeğin kullanılmasını desteklerken (örn; Rauthmann ve Kolar, 2012), diğer bazı araştırmacılar ölçeğin üç kişilik özelliğini ölçmek için fazla kısa olduğuna ve psikometrik özelliklerinin yetersiz olduğuna dair eleştirilerde bulunmuşlardır (örn; Lee ve ark., 2012). Sıklıkla kullanılan ikinci bir ölçek ise, psikometrik özellikleri bakımından Kirli Düzine'ye kıyasla daha üstün olduğu bulunan (Muris, Merckelbach, Otgaar ve Meijer, 2017) Jones ve Paulhus'un 2014 yılında geliştirdiği Kısa Karanlık Üçlü'dür (Short Dark Triad) (SD3). Bu ölçek, her bir kişilik özelliği için 9'ar madde olmak üzere toplamda 27 maddeden oluşmaktadır ve ölçeğin güvenirlik katsayısı .68 ve .74 arasında değişmektedir (Jones ve Paulhus, 2014).

Diğer taraftan Karanlık Üçlü’yü oluşturan Narsisizm, Makyavelizm ve Psikopati’yi ayrı ayrı ölçekler 
kullanarak ölçmek de mümkündür. Bu özellikleri ölçmek için kullanılan araçlar sayıca fazla olsalar da bunlardan bazıları standart ölçme aracı olarak kabul edilip alanda yaygın olarak kullanılmaktadır. Eşik altı Narsisizm'in ölçümünde en yaygın olarak kullanılan ölçek 1979 yılında Raskin ve Hall tarafından geliştirilmiş olan Narsisistik Kişilik Envanteri'dir (Narcissistic Personality Inventory) (NPI). 40 maddeden oluşan ölçekte her bir madde, biri narsisistik içeriğe sahip diğeri narsisistik içeriğe sahip olmayan iki seçenekten oluşur ve katılımcıdan bu iki maddeden kendisine uyanı seçmesi istenir (Raskin ve Hall, 1979). Ölçeğin 40 maddeden olușmas1 nedeniyle uzun bir ölçek olarak değerlendirilebileceği fikriyle 2006'da Ames, Rose ve Anderson tarafından 16 maddelik kısa formu geliştirilmiştir.

Makyavelizm'i ölçmek için en çok tercih edilen ölçek Christie ve Geis'ın 1970 yılında geliştirdikleri Mach-IV'tür. Ölçek 20 maddeden oluşmakta olup 5'li Likert tipi puanlamaya sahiptir (Christie ve Geis, 1970).

Eşik altı Psikopati'nin ölçülmesi için geliştirilen ölçeklerden Karanlık Üçlü alanında çalışan araştırmacılar tarafından en çok tercih edileni Paulhus, Neumann ve Hare tarafından 2009'da geliştirilen Öz-Bildirim Psikopati Ölçeği'dir (Self-Report Psychopathy Scale) (SRPIII). Ölçek 5'li Likert tipi cevap seçeneklerine sahip 64 maddeden oluşmaktadır (Paulhus, Neumann ve Hare, 2009). Sıklıkla kullanılan bir diğer ölçek ise 1996 yılında Lilienfeld ve Andrews tarafından geliştirilen ve hem klinik hem de sağlıklı evrende uygulamaya elveriş̧li olan Psikopatik Kişilik Envanteri'dir (Psychopathic Personality Inventory) (PPI) (Lilienfeld ve Andrews, 1996). Son olarak, araştırmacılar içerik olarak daha çok antisosyal kişilik bozukluğunu ölçen araçlara yakın olduğu görülen ve 1995 yılında Levenson, Kiehl ve Fitzpatrick tarafından geliştirilen Levenson Öz-Bildirim Psikopati Ölçeği'ni (Levenson Self-Report Psychopathy Scale) (LSRP) kullanmayı da düşünebilirler.

Buraya kadar olan bölümde Karanlık Üçlü'de Narsisizm, Psikopati ve Makyavelizm kişilik özelliklerinin tanımları, benzerlikleri, farklılıkları, alt boyutları ve kullanılan belli başlı ölçme araçları ele alındı. Bundan sonraki bölümlerde ise bu üç kişilik özelliğiyle başetme stilleri ve iyi oluş hali arasındaki ilişkiler incelenecektir.

\section{Karanlık Üçlü Kişilik Özellikleri ve Başetme Stilleri Arasındaki İlişkiler}

Bireylerin karşılaştıkları stresli yaşam olaylarının yaratacağı olumsuz etkileri azaltmada kullanılan baş etme stilleri stresli durumlarla mücadele için önemli araçlardır. Pek çok farklı başetme stili arasından bireylerin hangisini kullanacağını belirleyen faktörlerden biri kişilik özellikleridir (Birkás, Gács ve Csathó, 2016). Genel olarak, stresli durumlarla baş etmede daha aktif yöntemlerin seçilmesi, duygusal tepkiler vermeye ya da kaçınma davranışı göstermeye kıyasla daha işlevsel olarak değerlendirilmektedir. Bu aktif başetme biçimine çoğunlukla problem- veya görev-odaklı başetme, daha az işlevsel olanlara ise duygu-odaklı ve kaçınmacı başetme denmektedir (Endler ve Parker, 1994). Bu durum, üç başetme stilinin psikolojik sağlıkla olan ilişkisinde de görülebilmektedir. Görev-odaklı başetme ve psikolojik sağlık arasındaki ilişsi pozitifken, diğer iki başetme stili ve psikolojik sağlık arasında çoğunlukla negatif ilişki olduğu görülmüştür (Endler ve Parker, 1990).

Başetme stillerinin seçimi duruma göre değiştiği gibi aynı zamanda kişilik özelliklerine bağlı olarak da değişebilmektedir (Folkman ve Moskowitz, 2004); çünkü kişilik özellikleri stresi nasıl algıladığımızla ilişkili olmaktadır. Birkás, Gács ve Csathó (2016) kișilik özelliklerinin farklı başetme stillerinin seçiminde oynadığ rolü de göz önünde bulundurarak Karanlık Üçlü’nün başetme stilleriyle olan ilişkilerini incelemişlerdir. Araştırmacılar hem Makyavelizm hem de Psikopati ile görev-odaklı baş etme arasında negatif ilișki bulmuşlardır. Diğer bir deyişle bu bireyler stresli durumlarla karşılaştıklarında problemi aktif bir şekilde çözmeye çalışmamışlardır. Narsisistler ise kaçınmacı başetme stilini tercih etmemiş, onun yerine görev-odaklı başetmeyi kullanmışlardır.

Başetme stilleri Folkman ve Lazarus'un (1988) modeline dayandırılarak geliştirilen, Başaçıkma Yolları Envanteri (Ways of Coping Questionnaire) kullanılarak ölçüldügünde de benzer sonuçlar elde edilmiştir. Narsisizm, planlayarak problem çözme (planful problem solving) ve kendini kontrol etme (self-controlling) gibi sağlıklı başetme stratejileriyle pozitif ilişkili, kaçma-kaçınma (escape-avoidance) ile ise negatif ilişkili bulunmuştur (Birkás, Gács ve Csathó, 2016). Elde edilen sonuçlar değerlendirildiğinde Narsisistik özellikleri ağır basan bireylerin, stres yaratan durumlar karşısında aktif başetme stratejilerini kullandıkları ve daha sıklıkla kendi duygularını kontrol altında tutmaya çalıştıkları söylenebilir.

Diğer taraftan Narsisizm, sorumluluk kabul etmeyle (accepting responsibility) negatif ilişkili, olumlu şekilde yeniden değerlendirme (positive reappraisal) ile pozitif ilişkili bulunmuştur (Birkás, Gács ve Csathó, 2016). Bu bulgu Narsisistlerin, grandiyöz benlik algılarına tehdit oluşturan inançları göz ardı etme eğilimleriyle uyuşmaktadır (Paulhus ve Williams, 2002). Ayrıca Makyavelizm ve Psikopati sosyal destek arayışı ile negatif ilişkilidir; bu da, bu kişilik özelliklerine sahip bireylerin diğer insanlara karşı kuşkucu ve sömürücü bir tavır takınmaları ile açıklanabilir (Christie ve Geis, 1970). Psikopatiden farklı, Narsisizme benzer olarak, Makyavelizm de olumlu şekilde yeniden değerlendirme ile pozitif ilişkiye sahiptir (Birkás, Gács ve Csathó, 2016). Bu da 
Makyavelistlerin stresli durumlar karşısında aktif olarak başetmeye çalışmasalar da kendi duygularını kontrol altında tutmaya çalışmalarıyla açıklanabilir. Bunun dışında, sadece Psikopatinin yüzleşmeci (confrontive) başetme stratejisi ile pozitif ilişkisi olduğu saptanmıştır. Psikopatisi yüksek bireylerin strese karşı toleranslarının düşük olması ve kişilerarası ilişkilerde tercih ettikleri düşmanlık içeren tutumları bu ilişkiyi desteklemektedir (Birkás, Gács ve Csathó, 2016).

Psikopatide saldırganlık eğilimleriyle ilgili olarak yaptığı çalışma sonucunda Hasking (2007) ergenlerde suça yatkınlıkla problem çözme stratejilerinin negatif ilişkili olduğunu, kaçınmacı başetmenin ise pozitif ilişkili olduğunu bulmuştur. Gillen, Barry ve Bater (2016) İkincil Psikopati ve ergenlikte madde kullanımıyla ilgili sorunlar arasındaki ilişkide, kaygı ve alkol/esrar kullanarak başetmenin aracı rol oynadığını göstermișlerdir. Araştırmacılar özellikle İkincil Psikopatideki dürtüsellik ve sorumsuzluğun, Birincil Psikopati özelliklerine kıyasla madde kullanımılla ilgili sorunlar ve kaygı belirtilerini daha güçlü şekilde yordadığını saptamışlardır. Ayrıca, madde kullanarak başetmenin daha işlevsel olabilecek başetme stratejilerinin kullanımını kısıtlayabileceğinden daha problemli bir başetme stili olduğuna dikkat çekilmiştir. Bununla ilişkili olarak başetme stratejilerine ve kaygı belirtilerine yönelik yapılacak müdahalelerin madde kullanımıyla ilgili sorunları ortadan kaldırabileceği vurgulanmıştır (Gillen, Barry ve Bater, 2016).

Pastwa-Wojciechowska, Kaźmierczak ve Błażek (2012) Psikopati kişilik özelliğine sahip bireylerin, daha çok duygu-odaklı ve kaçınmacı başetme stillerini kullandıklarını belirtmişlerdir. Diğer bir deyişle, stresli durumlar karşısında ya dikkatlerini kendi öfkelerine çevirirler, ya da düşünmekten ve hislerine odaklanmaktan kaçınırlar. Bu bulgunun Psikopatisi yüksek olan bireylerin saldırganlıkları, benmerkezcilikleri ve benmerkezciliğe bağlı olarak diğerlerinin acılarını hissedememeleriyle ilişkili olduğu söylenebilir. Yapılan diğer bir çalışmada Campbell ve Elison (2005) Birincil ve İkincil Psikopatların utanç duygusuyla nasıl baş ettiklerini araştırmışlardır. Bu çalışmaya göre Birincil Psikopatların diğerlerine saldırı (attacking others) ve kaçınma gibi dışsallaştırma (externalizing) stratejilerini, İkincil Psikopatların ise hem dışsallaştırma hem de kendine saldırı (attacking self) ve geri çekilme (withdrawal) gibi içselleştirme (internalizing) stratejilerini tercih ettikleri görülmüştür. Birincil ve İkincil Psikopatinin belirli başetme stilleri birbirlerinden farklılık gösterse de, her ikisinde de işlevsel olmayan yöntemler kullanılmaktadır.

Narsisist bireylerin utanç duygusuyla başetme biçimlerinin incelendiği bir çalışmada Kealy, Ogrodniczuk, Rice ve Oliffe (2017) madde/alkol kullanımı gibi işlevsel olmayan yolların baş etmede kullanıldığını ve bu kişilerde daha sıklıkla dikkatsiz araba kullanma ve korunmasız cinsel ilişki gibi riskli davranışların görüldüğünü bulmuşlardır. Psikolojik sorunları olan Narsisist erkeklerin de madde kullanımı, saldırganlık, riskli davranışlarda bulunma gibi sağlıklı olmayan başetme yollarını kullandıkları görülmüştür. Araştırmacılar, Narsisistik özellikleri ağır basan erkeklerin alkol/madde kullanmalarını ve riskli davranışlarda bulunmalarını sarsılan benlik algılarını unutmak istemeleri ve düşük kendilik değerlerinin bir sonucu olan olumsuz ruh hallerini yükseltmeye çalışmaları şeklinde açıklamışlardır (Kealy, Ogrodniczuk, Rice ve Oliffe, 2017). Diğer taraftan Narsisist erkeklerin madde kullanımını ve riskli davranışları olumlu bir imaj yaratmak için bir araç olarak görüyor olabilecekleri ve kendilerini böyle davranarak yüceltmeye çalışıyor olabilecekleri de belirtilmiştir. Narsisizm ve saldırgan şekilde başetme arasındaki ilişki ise, Narsisizmi yüksek erkeklerin kendi güvensizliklerinin başka yere aktarılması olarak yorumlanmıştır (Kealy, Ogrodniczuk, Rice ve Oliffe, 2017). Benzer olarak Cisek, Hart ve Sedikides (2008) Narsisist bireylerin kendi güvensizlikleriyle, kendilerine karşı duydukları şüphe ve hissedilen acıyla maddi olanakların kullanılması yoluyla baş ettiklerini göstermişlerdir. Yani, Narsisistler diğer insanlarla içten ilişkiler kurmakta ve sürdürmekte zorlandıkları ve bu yüzden de sosyal destekten mahrum kaldıkları için maddi varlıklarını kendilerini yüceltmek için kullanıyor olabilirler.

Yapılan çalışmalarla paralel olarak Neckar (2013) Narsisistlerin kendini yüceltme davranışlarının işlevsel olan ve işlevsel olmayan yönlerini incelemiştir. İşlevsel yönlerine bakıldığında, duygu-odaklı başetme stilinin kullanılmasıyla geleceğe umutla bakma ve olumsuz duyguların tekrar etmesinden kaçınma belirgin olmuştur. $\mathrm{Bu}$ çalışmada Narsisizmin duygu-odaklı başetmeyi yordad1ğ1 bulunmuştur. İşlevsel olmayan yönüne bakıldığında ise yüksek Narsisizmin saf iyimserliği (naive optimism) (Epstein ve Meier, 1989) yordadığı görülmüştür. Saf iyimserlik kavramı fazla ve gerçekçi olmayacak şekilde olumlu bir bakış açısına sahip olmak şeklinde tanımlanmakta olup kişinin problemi doğru algılayamamasına sebep olmakta ve çözüm arayışına engel olmaktadır. Diğer bir deyişle Narsisizmde kendini yüceltme bir yandan olumsuz deneyimler üzerinde tekrarı azaltarak kişinin zorlu durumlarla başetmesini kolaylaştırırken, aynı zamanda kişinin durumu gerçekçi bir bakış açısıyla değerlendirip uygun olan davranışta bulunmasını zorlaştırmaktadır (Neckar, 2013).

Fernie, Fung ve Nikčević (2016) Kırılgan ve Grandiyöz Narsisistlerin stresli durumlar karşısında kullandıkları başetme stillerinin birbirinden farklı olduğunu belirlemişlerdir. Kırılgan Narsisistlerin başetme stratejisi olarak inkarı (denial) kullandıkları, yani stresin varl1- 
ğını yoksaydıkları (Carver ve ark., 1989), bunun da en belirgin olarak ihtiyaçlarının karşılanmamasından duydukları utanç sonucu ortaya çıktığının gözlendiği ifade edilmiştir (Fernie, Fung ve Nikčević, 2016). Buna ek olarak, Kırılgan Narsisistlerde davranışsal geri çekilme (behavioral disengagement) ile pozitif ilişki bulunurken, Grandiyöz Narsisistlerde negatif ilişki olduğu görülmüştür (Fernie, Fung ve Nikčević, 2016). Davranışsal geri çekilme, kişinin ümitsizlik yaşaması ve kötü sonuçlar beklemesi sonucunda amaçlarına ulaşmak için çabalamaktan vazgeçmesi olarak tanımlanmaktadır (Carver ve ark., 1989). Yani, stresli durumlarla karşılaştıklarında Kırılgan Narsisistlerin hedeflerinden vazgeçtikleri, Grandiyöz Narsisistlerin ise tam tersini yaptıkları söylenebilir. Aslında, Kırılgan Narsisistlerin teslimiyetçi yapılarına karşın Grandiyöz Narsisistlerin baskın yapıları olduğu düşünüldüğünde, bu bulgunun iki farklı Narsisizmin özellikleriyle uyuştuğu görülmektedir (Dickinson ve Pincus, 2003).

Diğer taraftan bazı araştırmacılar Kırılgan Narsisistlerin işlevsel olmayan başetme stillerini kullanmalarını bu bireylerin duygu-odaklı başetmeye olan yatkınlıklarına bağlarken (Carver ve ark., 1989), bazı araştırmacılar da Kırılgan ve Grandiyöz Narsisistlerin başetme stillerindeki bu farklılıkları onların başetme esneklikleri (coping flexibility) arasındaki farklılıklara bağlamışlardır (Ng, Cheung ve Tam, 2014). Başetme esnekliği kavramı Cheng (2001) tarafindan mevcut duruma göre farklı başetme stilleri arasından uygun olanı seçme becerisi olarak tanımlanmıştır. Örneğin, kontrol edilebilir durumlar karşısında problem-odaklı stratejiler daha uygun ve etkiliyken, kişinin kontrolü dışındaki durumlarda duygu-odaklı başetme stilinin kullanımı daha verimli olmaktadır. $\mathrm{Ng}$ ve arkadaşları (2014) tarafından yapılan bir araştırmada Grandiyöz Narsisistlerin, Kırılgan Narsisistlere göre daha yüksek seviyede başetme esnekliğine sahip oldukları ve bunun Grandiyöz Narsisizm ve psikolojik sağlık arasındaki pozitif ilişkiyi açıklayan faktörlerden biri olduğu bulunmuştur.

Sonuç olarak bu bölümde de ele alındığı üzere Karanlık Üçlünün alt kişilik özellikleri olan Narsisizm, Makyavelizm ve Psikopati kullanılan baş etme stilleri açısından da hem benzerlik hem de farklılıklar göstermektedir. Sadece üç kişilik özellik arasında değil aynı zamanda bu kişilik özelliklerinin alt faktörleri arasında da kullanılan baş etme stilleri farklılık gösterebilmektedir. Alanyazında belirtilen bu alt faktörlere ilişkin yeterli çalışma olmaması nedeniyle tercih edilen baş etme stilleri konusunda da yeterli bilgi bulunmamaktadır. Gelecekte bu konuda yapılacak çalışmalarda özellikle alt boyutların ayrı ayrı incelenmesinin önemli olacağı düşünülmektedir. Bunun en temel nedeni olarak alt boyutların birbirlerinden farklı özellikleri ortaya çıkarması ve farklı davranışlarla ilişkili bulunması gösterilebilir. Bu bölümde Karanlık Üçlü kişilik özellikleri ve bireylerin stresli durumlarda kullanmayı tercih ettikleri baş etme stilleri ile ilgili araştırmalar özetlenmiştir. Son bölümde ise Karanlık Üçlü kişilik özellikleri ve iyi oluş hali arasındaki ilişkiler alanyazındaki belli başlı çalışmalar çerçevesinde ele alınacaktır.

\section{Karanlık Üçlü ve İyi Oluş Hali Arasındaki İlişkiler}

Kişilik özelliklerinin hem psikolojik sağlık hem de fiziksel sağlık üzerinde önemli bir etkisi olduğu yaygın olarak kabul edilmektedir. Yaptıkları bir araştırmada, Hudek-Knežević, Kardum ve Mehić (2016) Karanlık Üçlü'nün hem pozitif/negatif ruh hali ve algılanan fiziksel sağlık gibi öznel sağlık ölçütleri ile hem de hastanede yatma sılı ı̆ 1 , geçirilen hastalıklar, kazalar, bağımlılık gibi nesnel sağlık ölçütleri ile olan ilişkilerini incelemişlerdir. Ayrıca araştırmacılar Karanlık Üçlü’nün sağlığı koruyucu davranışlarla olan ilişkisini de ele almışlardır. Çalışma sonucunda Psikopatinin hem öznel sağlık ölçütleriyle hem de sağlığı koruyucu davranışlarla negatif ilişkiye sahip olduğu görülmüştür. Ayrıca bu bulgu sosyoekonomik değişkenler ve Beş Faktör Modeli'ndeki kişilik özellikleri istatistiksel olarak kontrol edildikten sonra bile geçerliliğini korumaktadır. Bu yüzden, araştırmacılar Psikopatisi yüksek olan bireyler için sağlıklı alışkanlıklar kazandırmanın önemini vurgulamışlardır (Hudek-Knežević, Kardum ve Mehić, 2016).

Aynı araştırmada, Makyavelizmin düşük kaza riski ile ilişkisi olduğu; ancak diğer yandan da pozitif ruh haliyle negatif ilişkili olduğu bulunmuştur. Pozitif ruh halindeki bu düşüşün diğer insanlarla kurulan yüzeysel ve yetersiz ilişkilerle ilgili olabileceği düşünülmüştür (Hudek-Knežević, Kardum ve Mehić, 2016). Son olarak, Narsisizmin deri hastalıklarına yakalanma riskini düşürdüğ̈̈; ancak bunun dişında hiçbir sağlık ölçütünü yordamadığı belirlenmiştir. Narsisizmin deri hastalıklarıyla olan bu ilişkisinin, bu kişilik özelliğinin kendini yüceltmeyle olan ilişkisi çerçevesinde Narsisist bireylerin sağlıklarını korumak için değil de güzel bir dış görünüşe sahip olabilmek için verdikleri çabayla ilgili olabileceği öne sürülmüștür.

Jonason, Baughman, Carter ve Parker (2015) depresyon, kayg1, sosyal beceriler, öznel sağlık, ortalama yaşam süresi, risk-alma davranışları ve sağlıkla ilgili davranışlar gibi çeşitli psikolojik, sosyal ve fiziksel sağlık göstergeleri konusunda bir çalışma yapmışlardır. Buna göre Psikopati, düşük ortalama yaşam süresi ve hızlı yaşam tarihi stratejisi (fast life history strategy) ile ilişkili bulunmuştur. Hizlı yaşam tarihi stratejisi anlık kazançları tercih etme, riskli davranışlarda bulunma ve anı yaşama gibi özelliklerle tanımlanmaktadır (Giudice, 2014). Psikopatinin aksine, Makyavelizm ve Narsisiz- 
min yavaş yaşam tarihi stratejisi ile ilişkili olduğu görülmüştür. Araştırmacılar hızlı yaşam tarihi stratejisinin sağlık için belirgin bir şekilde daha zararlı olacağını vurgulamışlardır; ancak aynı zamanda da Makyavelistlerin yavaş yaşam tarihi stratejilerinin ve uzun vadeli stratejilerinin de sağlık bakımından olumsuz etkileri olabileceğine dikkat çekmişlerdir. Bunun en önemli nedeni anlık kazançları uzun vadeli amaçlar için ertelemenin stres yaratabilme olasılığıdır (Jonason, Baughman, Carter ve Parker, 2015). Ayrıca yine Psikopatiden farklı olarak, Makyavelizmin ortalama yaşam süresi ile ilişkisinin olmadığ1, hatta Narsisizmin daha uzun ortalama yaşam süresi ile ilişkili olduğu görülmüştür (Jonason, Baughman, Carter ve Parker, 2015).

Hızlı yaşam tarihi stratejisiyle çelişen bir bulgu, Karanlık Üçlü kişilik özelliklerinin ödömonik (eudemonic) ve hedonik (hedonic) iyilik hali ile olan ilişkilerini inceleyen bir çalışmada ortaya çıkarılmıştır (Aghababaei ve Błachnio, 2015). Ödömonik iyilik hali gelecek için yatırım yapabilmek için zahmetli olabilecek aktivitelerde bulunmayı gerektirirken, hedonik iyilik hali temel olarak anlık kazançlar edinme isteğiyle tanımlanmaktadır (Huta ve Ryan, 2010). Bu anlamda, ödömonik iyilik halinin yavaş yaşam tarihi stratejisine, hedonik iyilik halinin ise hızlı yaşam tarihi stratejisine benzediği söylenebilir. Hedonik iyilik halinin Narsisizm ile pozitif ilișkisi, diğer iki Karanlık Üçlü kişilik özelliğiyle ise negatif ilişkisi olduğu saptanmıştır. Yani Makyavelistler ve Psikopatların anlık kazançlar doğrultusunda hareket etmedikleri görülmüştür. Hedonik iyilik halinin yanısıra, Narsisizmin ödömonik iyilik hali ile de pozitif ilişkisi olduğu gözlenmiştir. Araştırmacılar, bu bulguları Karanlık Üçlü'nün işlevsellik anlamında birbirlerinden farklı olduğu, Narsisizmin her iki iyilik haliyle ilişkilerini değerlendirerek Narsisizmin Karanlık Üçlü içindeki daha "aydınlık" kişilik özelliği olduğu şeklinde yorumlamışlardır. Yine de, bu bulgular Karanlık Üçlü'nün olumsuz bir kavram olduğu gerçeğini değiştirmemektedir. Çünkü Karanlık Üçlü toplam puan olarak değerlendirildiğinde her iki tür iyilik haliyle de ya negatif ilişkilidir ya da anlamlı bir ilişki bulunmamaktadır (Aghababaei ve Błachnio, 2015).

Diğer taraftan Noser, Zeigler-Hill ve Besser (2014) Psikopatisi yüksek olan bireylerin, düşük olanlara k1yasla stresli bir durumla karşılaştıklarında daha düşük pozitif duygu durumuna sahip olduklarını bulmuşlardır. $\mathrm{Bu}$ da Psikopatların diğer insanlarla karşılaştırıldığında strese daha duyarlı oldukları ve daha çabuk rahatsızlık hissettikleri anlamına gelmektedir. Psikopatiden farklı olarak, Narsisizm için böyle bir bulguya rastlanmamıştır. Yani diğer bir deyişle, Narsisistik özelliklere sahip olan bireylerin diğer insanlarla karşılaştırıldığında stres duyarlılıkları önemli bir farklılık göstermemiştir. Ancak bu bulgu çalışmanın deseniyle ilgili olabilir; çünkü il- gili çalışmada yalnızca katılımcıların bir tatil sırasında yaşadıkları ufak çaplı stres deneyimlerine verdikleri tepkiler ölçülmüştür (Noser, Zeigler-Hill ve Besser, 2014). Bunun gibi daha az stresli durumlar Narsisistlerin grandiyöz benlik algılarını tehdit etmek için yetersiz kalmış olabilir ve Narsisistler için stres yaratmamış olabilir. Bunun yanısıra, Hill ve Roberts (2012) Narsisistik özelliklere sahip yetişkinlerin diğer insanlar tarafından daha nevrotik olarak algılandıklarını, Narsisistik ergenler ve genç yetişkinler için ise bu durumun geçerli olmadiğını bulmuşlardır. Bu yüzden, yaş Narsisistlerin stres duyarlılıklarını etkileyen diğer bir faktör olabilir.

Sedikides, Rudich, Gregg, Kumashiro ve Rusbult (2004) 5 ayrı çalışmadan oluşan kapsamlı bir araştırma yapmışlardır. $\mathrm{Bu}$ çalışmaların ilk üçünde Narsisizm, öz-saygı ve depresyon, yalnızlık, üzüntü, nevrotiklik, kayg1 gibi değişkenlerle iyilik hali arasındaki ilişkileri incelemişlerdir. $\mathrm{Bu}$ çalışmaların sonucunda, Narsisizmin iyilik hali ile pozitif ilişkisinin olduğu ve bu iliş̧ide öz-saygının aracı rol oynadığı görülmüştür. Yani, Narsisistik özellikleri ağır basan bireyler kötücül olmalarına rağmen psikolojik olarak sağlıklılar denebilir. Diğer iki çalışmada ise, araştırmacılar savunuculuk, bastırma ve etki yönetimi (impression management) gibi katılımc1ların cevaplarını etkileyebilecek faktörlerin var olup olmadığını test etmiş ve bulunan sonuçların Narsisistlerin abartılı derecede pozitif benlik algılarından kaynaklanmadığı sonucuna varmışlardır.

Buna paralel olarak, Zuckerman ve O'Loughlin (2009) de Narsisizmin iyilik hali ile pozitif ilişkisi olduğunu ve öz-saygının bu ilişkide aracı rol oynadığını bulmuşlardır. Diğer taraftan Fukushima ve Hosoe (2011) ise Narsisist bireylerin değişken benlik algılarının iyilik hali ile olan ilişkisini araştırarak durumu farklı bir perspektiften ele almışlardır. Katılımcıların yükselen Narsisizm puanlarıyla birlikte farklı kişilerarası rollerde ve farklı zaman dilimlerinde benlik algılarının yükseldiği ve bu değişkenliğin depresyon ve algilanan stres seviyesinde artışla ilişkisi olduğunu bulmuşlardır. Bireyin gün içinde değişen Narsisizm seviyesinin, öznel iyilik hali ile ilişkisine bakan benzer bir araştırmada da, Giacomin ve Jordan (2016) insanların yüksek yaşam doyumuna ve pozitif duygu durumuna sahip oldukları, özellikle de kendilerine güvenlerinin yüksek olduğu günlerde daha yüksek Narsisizm puanları aldıklarını ortaya çıkarmışlardır. Narsisizm ve öznel iyilik hali arasındaki bu ilişki öz-sayg1 değişkeni istatistiksel olarak kontrol edildikten sonra bile anlamlı olmaya devam etmiştir. Bu da katılımcıların Narsisistik özelliklerinin daha baskın olduğu zamanlarda öz-sayg1 seviyelerinden bağımsız olarak daha yüksek öznel iyilik haline sahip oldukları anlamına gelmektedir.

Başka bir çalışmada Love ve Holder (2014) Psikopatinin olumlu duygudurum, mutluluk ve yaşam doyu- 
mu ile negatif ilişkili olduğunu, olumsuz duygudurum ve depresyon ile ise pozitif ilişkili olduğunu bulmuştur. Diğer bir ifadeyle Psikopatisi yüksek olan bireylerin psikolojik sağlıklarının iyi olmadığı söylenebilir. Araştırmacılar bu bulguyu Psikopatların diğer insanlarla yetersiz ve yüzeysel ilişkiler kurmaları, duygu düzenleme ve duyguları tanıma güçlükleriyle açıklamışlardır. Bakır, Yılmaz ve Yavas (1996) tarafından yapılan çalışmada da Makyavelizm ve depresyon arasında benzer bir ilişki bulunmuştur. Araştırma sonuçları Makyavelistlerde depresyon görülme olasılığının daha yüksek olduğunu desteklemiştir.

Durand (2016) ise Birincil ve İkincil Psikopatinin kalıcı (durable) mutluluk, değişken (fluctuating) mutluluk, hayatın anlamı, kişisel gelişim ve umut ile olan ilişkilerini incelemiştir. Birincil Psikopati, değişken mutluluk ve hayatın anlamı dışındaki bütün iyilik hali değişkenleriyle pozitif ilişkili iken, İkincil Psikopati için tam tersi bir sonuç elde edilmiştir yani mutluluk ve hayatın anlamı dışındaki bütün iyilik hali değişkenleriyle negatif ilișkili çıkmıştır. Diğer bir ifadeyle Birincil Psikopati kalıcı mutluluk ile pozitif, değişken mutluluk ile negatif bir ilişkiye sahipken, İkincil Psikopati için sonuçlar tam tersi yönde olmuştur. Araştırmacılar bu durumu Birincil Psikopatide duygu kontrolünün başarılı olmasına ve İkincil Psikopatide ise duygusal değişkenliğin yüksek olmasına bağlamıșlardır.

Alanyazındaki tüm bu bulgulara bakıldığında, Psikopatinin Karanlık Üçlü içinde iyilik hali ile en güçlü negatif ilişkiye, Narsisizmin ise bu anlamda en güçlü pozitif ilişkiye sahip olduğu, Makyavelizmin ise ikisinin ortasında yer aldığı söylenebilir (Muris, Merckelbach, Otgaar ve Meijer, 2017). Bugüne kadar, alanyazında Karanlık Üçlü, iyilik hali ve başetme stilleri arasındaki ilişkilere bir arada ele alan yalnızca bir çalışmaya rastlanmıştır. Ancak bu çalışmada da yalnızca Psikopati ve Narsisizm kişilik özellikleri ele alınmıştır ve araştırma sadece erkek mahkumlarla yapılmıştır (Ireland, Brown ve Ballarini, 2006). Araştırmada psikosomatik belirtiler, kaygı, uykusuzluk, sosyal işlevsellikte bozulma ve ağır depresyon gibi birçok gösterge incelenmiş ve mahkumların Narsisizmi yükseldikçe iyilik hallerinin düştüğü, ayrıca duygu-odaklı ve kaçınmacı başetmenin bu ilişkide arac1 rol oynadığı gösterilmiştir. Bu yüzden, Narsisistik özellikleri yüksek olan mahkumların kullandıkları işlevsel olmayan başetme stilleriyle ilgili müdahalelerin önemi vurgulanmıştır. Bunun yanında, araştırmacılar Psikopati seviyeleri yüksek olan mahkumlar için benzer bir sonuç bulunamamasını bu mahkumlar için başetmenin hapishanede karşılaştıkları stresli durumlarda çok da önemli bir rol oynamıyor olabileceği ile açıklamışlardır. Yine de, bu çalışmada hem Narsisizm hem de Psikopatinin iyilik hali ile negatif ilişkilerinin olduğunun bu- lunması, kötücül kişilik özelliklerinin psikolojik sağlık üzerindeki etkisinin gösterilmesi açısından büyük öneme sahiptir.

Sonuç olarak Karanlık Üçlü kişilik özelliklerinin iyi oluş haliyle ilişkileri genel olarak negatif yönde bulunsa da elde edilen ilişskilerin üç kişilik özelliği için farkl1 göstergeleri olduğu görülmektedir. $\mathrm{Bu}$ bilgi bir yandan iyi oluş hali için üç kişilik özelliğin olumsuz değerlendirilebileceğini gösterirken hem de araştırmalarda bu üç özelliğin ayrı incelenmesinin önemini yeniden vurgulamaktadır.

\section{Sonuç ve Genel Değerlendirme}

Bu makalede alanyazında "Karanlık Üçlü” başlığı altında ele alınan üç kișilik özelliği, Narsisizm, Makyavelizm ve Psikopati, önceki çalışmalar çerçevesinde tanımlanmış ve benzerlikleri, farklılıkları ve alt boyutları konusunda alanda yapılan çalışmalar özetlenmiştir. Bu tartışma yapılırken Narsisizm, Makyavelizm ve Psikopati kişilik özellikleri tek bir özellik gibi mi yoksa birbirinden farklı üç özellik gibi mi araştırılmalı sorusu cevaplanmaya çalışılmış, aynı zamanda da Karanlık Üçlü'yü hem toplam puan olarak ölçerken hem de her bir kişilik özelliğini ayrı ayrı ölçerken en sık kullanılan ölçekler hakkında bilgi verilmiștir. Karşılaștırmalar özellikle bu üç kişilik özelliğinin stresle başa çıkma açısından farklılıkları ve iyi oluşla ilişkileri çerçevesinde yapılmıştır. Araştırmalar bu üç özelliği karanlık kişilikler olarak tanımlamış olsalar da alanda yapılan çalışmalar incelendiğinde her birinin karanlık olma derecelerinin birbirinden farklı olduğu ve üç özelliğin alt boyutları arasında da işlevsellik anlamında önemli farklılıklar olduğu göze çarpmaktadır.

Narsisizm, Makyavelizm ve Psikopati kişilik özelliklerinin en temel benzerliği kötü niyetli özellikleridir. Kötü niyetliliğin hangi temel özellikle açıklanabileceği Jones ve Paulhus (2011), Jakobwitz ve Egan (2006), Lee ve Ashton (2005), Lynam ve Derefinko (2005) gibi araştırmacılar tarafından ele alınmıştır. Araştırmacılar bu üç karanlık kişiliğin açıklanmasında kullanılabilecek ortak bir kavramı araştırırken, bazı diğer araştırmacılar ise aslında bu kişilik özelliklerinin birbirlerinden oldukça farklı olduklarını vurgulamışlardır (örn., Christie ve Geis, 1970; Furnham, Richards ve Paulhus, 2013; Paulhus ve Williams, 2002). Bu farklılık araştırılırken Narsisizm, Makyavelizm ve Psikopatinin özellikle diğer kişilik özellikleriyle olan ilişkileri arasındaki farklılıklar da bu bulguya destek olur niteliktedir. Diğer taraftan bu derlemede ele alınan ve Karanlık Üçlü çalışmaları için oldukça önemli olan bir konu ise bu üç özelliğin alt boyutlarıdır. Furnham, Richards ve Paulhus (2003), Rauthmann ve Kolar (2012) gibi araştırmacılar bu alt boyutla- 
rın araştırmalara dahil edilmesinin önemini vurgulamış olsalar da hemen hemen hiçbir çalışmada Narsisizm, Makyavelizm ve Psikopati'nin alt boyutları bir arada incelenmemiştir. $\mathrm{Bu}$ nedenle gelecekte yapılacak çalışmaların özellikle bu boyutlara önem vermelerine ihtiyaç duyulmaktadır.

Diğer taraftan Karanlık Üçlü kişilik özellikleri ve stresle başetme stilleri arasındaki ilişkiler incelendiğinde genel olarak üç kişilik özelliğinin de işlevsel olmayan başetme stillerini işlevsel olanlara oranla daha çok kullandıkları görülmüştür. Karanlık Üçlü kendi aralarında karşılaştırıldığında ise, Makyavelizm ve Psikopatinin Narsisizme göre kaçınmacı baş etmeyle daha çok ilişkili olduğu bulunmuştur (örn., Birkás, Gács ve Csathó, 2016; Hasking, 2007). Diğer taraftan yapılan baz1 araştırmalarda stresle baş etme stilleri açısından kișilik özelliklerinin alt boyutları arasında farkl1lıklar olduğu bulunmuştur. $\mathrm{Bu}$ çalışmalarda Psikopatinin Birincil ve İkincil Psikopati boyutları arasında (örn., Campbell ve Elison, 2005; Gilen, Barry ve Bater, 2016), Narsisizmin ise Kırılgan ve Grandiyöz boyutları arasında (örn., Fernie, Fung ve Nikcevic, 2016; Ng, Cheung ve Tam, 2014) farklılıklar bulunmuştur. Bu sonuçlar Karanlık Üçlüyle ilgili yapılacak araştırmalarda kişilik özelliklerinin alt boyutlarına ilişkin bilgi toplanmasının önemini desteklemektedir

Karanlık Üçlü kişilik özellikleri ve iyilik hali çalışmaları incelendiğinde de farklı iyi olma göstergeleri için bu üç kişilik özelliğinin bir öncül olarak değerlendirilebileceği görülmektedir ve genel olarak değerlendirildiğinde Karanlık Üçlü'nün iyi olma haliyle negatif ilişkide olduğu söylenebilir (örn., Aghababaei ve Blachnio, 2015; Hudek-Knezevic, Kardum ve Mehic, 2016; Jonason ve ark., 2015). Yine Karanlık Üçlü kendi aralarında karşılaştırıldığında, bu üç kişilik özelliği arasında daha çok Narsisizmin iyilik haliyle pozitif ilişkili olduğu bulunmuştur (örn., Jonason ve ark., 2015; Sedikides ve ark., 2004; Zuckerman ve O'Loughlin, 2009). Ancak bu olumlu bulgu Narsisizm'in diğer olumsuz psikososyal sonuçları göz önüne alındığında karanlık özellikler içindeki en az karanlık olan özellik olması dışında çok da olumlu değerlendirilememektedir. Baş etme stillerine benzer şekilde, iyilik hali açısından da kişilik özelliklerinin alt boyutları arasında farklılıklar olduğu görülmüştür. $\mathrm{Bu}$ araştırmalarda Narsisizmin Liderlik/Otorite, Grandiyöz Gösterişçilik ve Hak İddia Etme/Sömürücülük boyutlarına (örn., Clarke, Karlov ve Neale, 2015) ve Kırılgan ve Grandiyöz boyutlarına göre (örn., Egan, Chan ve Shorter, 2014; Rose, 2002), Psikopatinin ise Birincil ve İkincil Psikopati boyutlarına göre (örn., Durand, 2016) farklılıklar bulunmuştur.

Tüm bu bulgular gelecekte Karanlık Üçlü konusunda yapılacak çalışmalarda bu özelliklerin alt boyutlarının da ele alınmasının sonuçlar açısından önemli olduğunu göstermektedir. Karanlık Üçlü çalışmalarında alt boyutların da dahil edilmesi gereğinin belki de en önemli sebebi her bir kişilik özelliğinin kendi içinde işlevsel olan ve olmayan yönlerinin daha net anlaşılmasıdır. Bu derlemede bahsedilen çalışmalarda alt boyutların işlevsellik anlamında birbirlerinden oldukça farklı olabildikleri ve temel kavramlarla farklı ilişkilere sahip olabildikleri rahatlıkla görülebilmektedir. Gelecekte yapılacak olan çalışmalarda Karanlık Üçlü'yü oluşturan kişilik özelliklerinin, özellikle faktör yapısı konusunda çok az araştırma bulunan Makyavelizm'in, alt boyutları arasındaki farklılıklar incelenerek her bir karanlık kişilik özelliğinin işlevsel ve işlevsel olmayan yönleri tespit edilebilir. Bu bulgular 1şı̆̆ında da, bireylerde Karanlık Üçlü kişilik özelliklerinin alt boyutlarından hangileri bulunduğuna bakılarak, buna uygun daha spesifik farkındalık kazandırma, sağlıklı başetme stillerinin kullanımını destekleme ve olumlu sağlık alışkanlıklarının kazandırılması için müdahale programlarının geliştirilmesi sağlanabilir.

Her üç kişilik özelliği de olumsuz kişilerarası ilişkiler, etik ve ahlaki değerleri yoksayan davranışlar ve antisosyal eğilimler göstermeleri açısından büyük benzerlikler gösterseler de, her biri hem diğer temel kişilik özellikleriyle ve kavramlarla olan ilişkileri, hem de stresle baș etme stratejileri ve iyi oluş hali ile olan ilişkileri bakımından birbirlerinden ayırt edilebilecek ve ayrı ayrı ölçmeye gerek duyulacak ölçüde farklılık göstermektedirler. Bu anlamda üç kişilik özelliği arasındaki önemli bir farklılık olan "karanlık olma" dereceleri de göz önüne alındığında, her ne kadar Narsisizm diğer iki Karanlık Üçlü kişilik özelliğine göre daha az karanlık, yani daha işlevsel yönlere sahip olsa da, Narsisizm'in de olumsuz psikososyal sonuçlarının olumlulara göre daha fazla olduğu unutulmamalıdır (Paulhus ve Williams, 2002; Rauthmann ve Kolar, 2012).

$\mathrm{Bu}$ derlemeden de anlaşılabileceği üzere, Karanlık Üçlü kişilik özelliklerine sahip bireylerin genel olarak stresle baş etmede işlevsel olmayan stratejileri kullandıkları, bunun sonucunda da iyi oluş hallerinin olumsuz etkilendiği görülmüştür. Bu nedenle, Karanlık Üçlü kişilik özellikleri ağır basan bireylere işlevsel baş etme stratejileri kazandırmak hem kendi ruh sağlıklarını hem de çevreyle olan ilişkilerini iyileştirme bakımından büyük önem taşımaktadır. Nitekim stresli durumlarla işlevsel bir şekilde baş edemeyen Karanlık Üçlü kişilik özelliklerine sahip bireylerin etik kuralları yok sayması ve antisosyal davranışlarda bulunması daha da olasıdır. Oysaki, bu bireylerin stresle işlevsel şekilde baş etmeleri sağlanabilirse, kişilerarası ilişkilerinde ve çalıştıkları ortamlarda bulundukları olumsuz davranışların da azalması beklenebilir. Bu da hem bireysel hem de toplumsal boyutta büyük fayda sağlayacaktır. 
Son olarak "Dark Triad" (Karanlık Üçlü) anahtar kelimesi PsycINFO arama sistemi içerisinde tarand1ğında, tüm tarihler için basılı 400 civarı çalışma olduğu görülmektedir. Bu tarama Türkiye'de yapılmış basılı araştırmalar için yapıldığında araştırmaların 20-30'lu sayılarda olduğu ancak bu sayının son yıllarda artış gösterdiği belirlenmiştir. Bu ilginin özellikle son yıllarda Karanlık Üçlü ve çalışan davranışlarıyla ilgili çalışmalarda daha fazla olduğu söylenebilir. İşyerinde çalışanların \%33 ila \%75'inin hırsızlık, sahtekarlık, sabotaj, vandallık ve bilinçli devamsızlık gibi olumsuz davranışlarda bulunduğu tahmin edilmektedir (Cohen, 2016). Cohen (2016) bunun gibi olumsuz işyeri davranışlarının ilgi çeken bir konu olmasına rağmen davranışların öncüllerinin belirgin olmadığına dikkat çekmiştir. Nitekim Karanlık Üçlü bu davranışların belirleyicileri olabilir (Smith ve Lilienfeld, 2013). Son yıllarda yapılan çeşitli çalışmalarda da Makyavelizmin etik olmayan davranışlarla (örn.,-Kish-Gephart, Harrison ve Trevino, 2010), Karanlık Üçlünün işyeri karşıtı davranışlarla (örn.,O’Boyle, Forsyth, Banks ve McDaniel, 2012; Palmer, Komarraju, Carter ve Karau, 2017) ilişkili olduğu gösterilmiştir. Ancak yapılan çalışmalar sınırlı sayıdadır. Nitekim yeni çalışmalarda Karanlık Üçlünün alt boyutlarının da ele alındığı kapsamlı çalışmalara ihtiyaç duyulmaktadır.

\section{Kaynaklar}

Ackerman, R. A., Witt, E. A., Donnellan, M. B., Trzesniewski, K. H., Robins, R. W., \& Kashy, D. A. (2011). What does the narcissistic personality inventory really measure? Assessment, 18(1), 67-87. http://dx.doi.org/10.1177/1073191110382845

Aghababaei, N., \& Błachnio, A. (2015). Well-being and the dark triad. Personality and Individual Differences, 86, 365-368.

Bakir, B., Yilmaz, U. R., \& Yavas, I. (1996). Relating depressive symptoms to machiavellianism in a turkish sample. Psychological Reports, 78, 1011-1014.

Berg, J. M., Smith, S. F., Watts, A. L., Ammirati, R., Green, S. E., \& Lilienfeld, S. O. (2013). Misconceptions regarding psychopathic personality: Implications for clinical practice and research. Neuropsychiatry, 3(1), 63-74.

Birkás, B., Gács, B., \& Csathó, A. (2016). Keep calm and don't worry: Different dark triad traits predict distinct coping preferences. Personality and Individual Differences, 88, 134-138.

Buelow, M. T., \& Brunell, A. B. (2014). Facets of grandiose narcissism predict involvement in health-risk behaviors. Personality and Individual Differences, 69, 193-198.

Campbell, J. S., \& Elison, J. (2005). Shame coping styles and psychopathic personality traits. Journal of Personality Assessment, 84(1), 96-104.

Cheng, C. (2001). Assessing coping flexibility in real-life and laboratory settings: A multimethod approach. Journal of Personality and Social Psychology, 80(5), 814-833.

Christie, R., \& Geis, F. L. (1970). Studies in machiavellianism. New York, NY: Academic Press.

Cisek, S. Z., Hart, C. M., \& Sedikides, C. (2008). Do narcissists use material possessions as a primary buffer against pain? Psychological Inquiry, 19, 205-207.

Clarke, I. E., Karlov, L., \& Neale, N. J. (2015). The many faces of narcissism: Narcissism factors and their predictive utility. Personality and Individual Differences, 81, 90-95.

Cleckley, H. M. (1976). The mask of sanity (5th ed.). St. Louis, MO: Mosby.

Corral, S., \& Calvete, E. (2000). Machiavellianism: Dimensionality of the mach IV and its relation to self-monitoring in a spanish sample. The Spanish Journal of Psychology, 3(1), 3-13.

Costa, P. T., McCrae, R. R., \& Dye, D. A. (1991). Facet scales for agreeableness and conscientiousness: A revision of the neo personality inventory. Personality and Individual Differences, 12(9), 887-898. 
Demircioğlu, Z. I., \& Köse, A. G. (2018). Effects of attachment styles, dark triad, rejection sensitivity, and relationship satisfaction on social media addiction: A mediated model. Current Psychology, 1-15.

Durand, G. (2016). Demystificatin of the relationship between psychopathy and happiness. Journal of Happiness Studies, 1-15.

Egan, V., Chan, S., \& Shorter, G. W. (2014). The dark triad, happiness and subjective well-being. Personality and Individual Differences, 67, 17-22.

Emmons, R. A. (1987). Narcissism: Theory and measurement. Journal of Personality and Social Psychology, 52(1), 11-17.

Endler, N. S., \& Parker, J. D. A. (1990). Multidimensional assessment of coping: A critical evaluation. Journal of Personality and Social Psychology, 58(5), 844-854.

Endler, N. S., \& Parker, J. D. A. (1994). Assessment of multidimensional coping: Task, emotion, and avoidance strategies. Psychological Assessment, 6(1), 50-60.

Erdoğan, B. (2018). Karanlık üçlü kişilik özelliklerine sahip üniversite ögrencileriyle kendine zarar verme davranışı gösterenlerin saldırganlık ve risk alma davranışlarının karşılaştırılması. (Yayımlanmamış yüksek lisans tezi). İstanbul Üniversitesi/ Adli Tıp Enstitüsü, İstanbul.

Fernie, B. A., Fung, A., \& Nikčević, A. V. (2016). Different coping strategies amongst individuals with grandiose and vulnerable narcissistic traits. Journal of Affective Disorders, 205, 301-305.

Folkman, S., \& Moskowitz, J. T. (2004). Coping: Pitfal1s and promise. Annual Review of Psychology, 55, $745-774$.

Fukushima, O., \& Hosoe, T. (2011). Narcissism, variability in self-concept, and well-being. Journal of Research in Personality, 45, 568-575.

Furnham, A., Richards, S. C., \& Paulhus, D. L. (2013). The dark triad of personality: A 10 year review. Social and Personality Psychology Compass, 7(3), 199-216.

Giacomin, M., \& Jordan, C. H. (2016). Self-focused and feeling fine: Assessing state narcissism and its relation to well-being. Journal of Research in Personality, 63, 12-21.

Gillen, C. T. A., Barry, C. T., \& Bater, L. R. (2016). Anxiety symptoms and coping motives: Examining a potential path to substance use-related problems in adolescents with psychopathic traits. Substance Use and Misuse, 51(14), 1920-1929.

Giudice, M. D. (2014). An evolutionary life history framework for psychopathology. Psychological Inquiry, 25, 261-300.
Hare, R. D., Harpur, T. J., Hakstian, A. R., Forth, A. E., Hart, S. D., \& Newman, J. P. (1990). The revised psychopathy checklist: Reliability and factor structure. A Journal of Consulting and Clinical Psychology, 2(3), 338-341.

Hare, R. D., \& Neumann, C. S. (2008). Psychopathy as a clinical and empirical construct. Annual Review of Clinical Psychology, 4, 217-246.

Hasking, P. A. (2007). Reinforcement sensitivity, coping, and delinquent behavior in adolescents. Journal of Adolescence, 30, 739-749.

Hill, P. L., \& Roberts, B. W. (2012). Narcissism, well-being, and observer-rated personality across the lifespan. Social Psychological and Personality Science, 3(2), 216-223.

Hudek-Knežević, J., Kardum, I., \& Mehić, N. (2016). Dark triad traits and health outcomes: An exploratory study. Psychological Topics, 25(1), 129-156.

Huta, V., \& Ryan, R. M. (2010). Pursuing pleasure or virtue: The differential and overlapping well-being benefits of hedonic and eudaimonic motives. Journal of Happiness Studies, 11, 735-762.

Ireland, J. L., Brown, S. L., \& Ballarini, S. (2006). Maladaptive personality traits, coping styles and psychological distress: A study of adult male prisoners. Personality and Individual Differences, 41, 561-573.

Jakobwitz, S., \& Egan, V. (2006). The dark triad and normal personality traits. Personality and Individual Differences, 40, 331-339.

Johnson, V. A., Beehr, T. A., \& O’Brien, K. E. (2015). Determining the relationship between employee psychopathy and strain: Does the type of psychopathy matter?. International Journal of Stress Management, 22(2), 111-136.

Jonason, P. K., Baughman, H. M., Carter, G. L., \& Parker, P. (2015). Dorian gray without his portrait: Psychological, social, and physical health costs associated with the dark triad. Personality and Individual Differences, 78, 5-13.

Jonason, P. K., Li, N. P., Webster, G. D., \& Schmitt, D. P. (2009). The dark triad: Facilitating a short-term mating strategy in men. European Journal of Personality, 23(1), 5-18.

Jones, D. N., \& Paulhus, D. L. (2011). Differentiating the dark triad within the interpersonal circumplex. In L. M. Horowitz \& S. Strack (Eds.), Handbook of interpersonal psychology: Theory, research, assessment, and therapeutic interventions (pp. 249269). New York, NY: Wiley \& Sons.

Karpman, B. (1941). On the need of separating psychopathy into two distinct clinical types: The symptomatic and the idiopathic. Journal of Criminal Psychopathology, 3, 112-137. 
Kealy, D., Ogrodniczuk, J. S., Rice, S. M., \& Oliffe, J. L. (2017). Pathological narcissism and maladaptive self-regulatory behaviors in a nationally representative sample of canadian men. Psychiatry Research, 256, 156-161.

Kircaburun, K., Demetrovics, Z., \& Tosuntaş, Ş. B. (2018). Analyzing the links between problematic social media use, dark triad traits, and self-esteem. International Journal of Mental Health and Addiction, 1-12.

Lee, K., \& Ashton, M. C. (2005). Psychopathy, machiavellianism, and narcissism in the five-factor model and the hexaco model of personality structure. Personality and Individual Differences, 38, 1571-1582.

Lee, K., Ashton, M. C., Wiltshire, J., Bourdage, J. S., Visser, B. A., \& Gallucci, A. (2012). Sex, power, and money: Prediction from the dark triad and honesty-humility. European Journal of Personality, 27, 169-184.

Lee, Z., \& Salekin, R. T. (2010). Psychopathy in a noninstitutional sample: Differences in primary and secondary subtypes. Personality Disorders: Theory, Research, and Treatment, 1(3), 153-169.

Levenson, M. R., Kiehl, K. A., \& Fitzpatrick, C. M. (1995). Assessing psychopathic attributes in a noninstitutionalized population. Journal of Personality and Social Psychology, 68(1), 151-158.

Love, A. B., \& Holder, M. D. (2014). Psychopathy and subjective well-being. Personality and Individual Differences, 66, 112-117.

Lynam, D. R., \& Derefinko, K. (2005). Psychopathy and personality. In C. J. Patrick (Ed.), Handbook of psychopathy (pp. 133-155). New York, NY: Guilford.

Monaghan, C., Bizumic, B., \& Sellbom, M. (2016). The role of machiavellian views and tactics in psychopathology. Personality and Individual Differences, 94, 72-81.

Muris, P., Merckelbach, H., Otgaar, H., \& Meijer, E. (2017). The malevolent side of human nature: A meta-analysis and critical review of the literature on the dark triad (narcissism, machiavellianism, and psychopathy. Perspectives on Psychological Science, 12(2), 183-204.

Neckar, J. (2013). Self-enhancement and coping: The costs and benefits of positive illusions. Studia Psychologica, 55(4), 299-309.

Ng, H. K. S., Cheung, R. Y., \& Tam, K. (2014). Unraveling the link between narcissism and psychological health: New evidence from coping flexibility. Personality and Individual Differences, 70, 7-10.

Noser, A. E., Zeigler-Hill, V., \& Besser, A. (2014). Stress and affective experiences: The importance of dark personality features. Journal of Research in Personality, 53, 158-164.

Özsoy, E., Rauthmann, J. F., Jonason, P. K., \& Ardıç, K. (2017). Reliability and validity of the Turkish versions of dark triad dirty dozen (DTDD-T), short dark triad (SD3-T), and single item narcissism scale (SINS-T). Personality and Individual Differences, 117, 11-14.

Pastwa-Wojciechowska, B., Kaźmierczak, M., \& Błażek, M. (2012). Self-esteem and styles of coping with stress versus strategies of planning in people with psychopathic personality disorders. Medical Science Monitor, 18(2), 119-124.

Paulhus, D. L., \& Williams, K. M. (2002). The dark triad of personality: Narcissism, machiavellianism, and psychopathy. Journal of Research in Personality, 36, 556-563.

Rauthmann, J. F., \& Kolar, G. P. (2012). How "dark" are the dark triad traits? Examining the perceived darkness of narcissism, machiavellianism, and psychopathy. Personality and Individual Differences, 53, 884-889.

Rose, P. (2002). The happy and unhappy faces of narcissism. Personality and Individual Differences, 33, 379-391.

Sedikides, C., \& Gregg, A. P. (2008). Self-enhancement: Food for thought. Perspectives on Psychological Science, 3(2), 102-116.

Sedikides, C., Rudich, E. A., Gregg, A. P., Kumashiro, M., \& Rusbult, C. (2004). Are normal narcissists psychologically healthy?: Self-esteem matters. Personality Processes and Individual Differences, 87(3), 400-416.

Wiggins, J. S. (1979). A psychological taxonomy of trait-descriptive terms: The interpersonal domain. Journal of Personality and Social Psychology, 37(3), 395-412.

Zeigler-Hill, V., \& Vonk, J. (2015). Dark personality features and emotion dysregulation. Journal of Social and Clinical Psychology, 34(8), 692-704.

Zuckerman, M., \& O'Loughlin, R. E. (2009). Narcissism and well-being: A longitudinal perspective. European Journal of Social Psychology, 39, 957-972. 


\section{Summary \\ Dark Triad Personality: Narcissism, Machiavellianism, and Psychopathy}

\author{
Seren Saltoğlu \\ Bahçeşehir University
}

The Dark Triad reveals the malevolent side of human beings and consists of the personality traits Narcissism, Machiavellianism, and Psychopathy which have recently begun to be a subject of interest to the studies with the term Dark Triad revealed by Paulhus and Williams (2002). People who are high in the Dark Triad traits often disregard moral values and social norms and engage in socially-aversive behaviors such as lying, cheating, deception, and bullying (Muris, Merckelbach, Otgaar, \& Meijer, 2017). They are also likely to employ ineffective coping strategies (e.g.; Birkás, Gács, \& Csathó, 2016; Kealy, Ogrodniczuk, Rice, \& Oliffe, 2017), which make them more vulnerable to the negative consequences of a stressful event and negatively affects their psychological well-being.

Sub-clinical narcissism is characterized by a lack of empathy, feelings of superiority, egocentricism, self-enhancement, arrogance, and manipulative behaviors (Emmons, 1987; Fernie, Fung, \& Nikčević, 2016; Sedikides \& Gregg, 2008). Machiavellianism is mostly defined by a cynical worldview and interpersonal manipulation (Furnham, Richards, \& Paulhus, 2013). In order to succeed, Machiavellians often make decisions based on the practical outcomes of a situation rather than the possible emotional consequences of their behavior (Zeigler-Hill \& Vonk, 2015). Lastly, sub-clinical psychopathy is described by deviant behaviors, a lack of empathy, remorselessness, disinhibition, a desire for dominance, and dishonesty (Cleckley, 1976).

In this literature review, the Dark Triad traits will be presented with their similarities and differences and their relationship with the major personality models. Moreover, facets of the three traits and frequently used measures of the construct will be introduced. Then, the relationships between the Dark Triad traits, different coping styles and psychological well-being will be discussed. The main aim of this literature review is to

\author{
Doruk Uysal Irak \\ Bahçeşehir University
}

provide a detailed Turkish reference for the researchers as Dark Triad has become a growing research interest.

\section{Similarities and Differences among the Dark Triad Traits}

Although the three traits have several common features, different opinions appear related to labeling them. Various researchers labeled common features differently including "callousness" and "manipulativeness" (Jones \& Paulhus, 2011), "low agreeableness" and "low conscientiousness" (Jakobwitz \& Egan, 2006), "low level of honesty-humility" (Lee \& Ashton, 2005), "interpersonal antagonism" (Lynam \& Derefinko, 2005), and "social exploitativeness" (Jonason, Li, Webster, \& Schmitt, 2009). On the other hand, some other researchers argued, there is no similarity between the Dark Triad traits and need to be measured separately. However, significant differences were found between the relations of the Dark Triad traits and the Big Five personality traits (Costa, McCrae, \& Dye, 1991; Paulhus \& Williams, 2002).

Moreover, the "darkness" levels of the Dark Triad traits are different, such as on a continuum, psychopathy falls on the darkest end, narcissism on the lightest, and Machiavellianism finds itself a place in the middle (Rauthmann \& Kolar, 2012). Nevertheless, although Machiavellianism and Narcissism are more adaptive personality traits compared to Psychopathy, the negative behavioral outcomes of all three Dark Triad traits outweigh the positive ones (Paulhus \& Williams, 2002; Rauthmann \& Kolar, 2012). Moreover, Narcissism, Machiavellianism, and Psychopathy have different relationships with other constructs such as self-enhancement (Christie \& Geis, 1970), intelligence (Paulhus \& Williams, 2002), and positive mood (Egan, Chan, \& Shorter, 2014). In other words, although the Dark Triad traits share some fundamental features, they are distinct enough and need to be measured separately.

Address for Correspondence: Asst. Prof. Doruk Uysal Irak, Bahçeşehir University, Faculty of Economics, Administrative and Social Sciences, Department of Psychology, Çırağan cad. Osmanpaşa Mektebi sokak No:4 Beşiktaş / İstanbul.

E-mail: doruk.uysalirak@eas.bau.edu.tr 


\section{The Relationship between the Dark Triad and the Major Personality Models}

The Dark Triad traits are correlated with Extraversion, Agreeableness, Conscientiousness, Openness to Experience, and Neuroticism which are dimensions of Big Five Personality Model (Costa, McCrae, \& Dye, 1991). According to that, people who are getting higher scores from the measures of Dark Triad traits, they also get lower scores from the measures of Agreeableness (Muris, Merckelbach, Otgaar, \& Meijer, 2017). Also Narcissists scored higher on both Openness to Experience and Extraversion (Hudek-Knežević, Kardum, \& Mehić, 2016), and both Machiavellians and Psychopaths get low scores on Conscientiousness (Muris et al., 2017). In addition, the three traits correlated differently with the facets of the Big Five dimensions of Agreeableness and Conscientiousness (Furnham, Richards, \& Paulhus, 2013).

The Dark Triad traits were also correlated with the Hexaco Model of personality, including the dimensions Extraversion, Openness to Experience, Agreeableness, Conscientiousness, Emotionality, and Honesty-Humility (Lee \& Ashton, 2005). People with higher scores in the Dark Triad traits were score lower on the Honesty-Humility dimension (Hudek-Knežević, Kardum, \& Mehić, 2016), which indicates that these people are not fair, sincere, faithful, honest, and trustful. Similarly the Dark Triad traits correlated differently with the facets of the Honesty-Humility dimension (Muris, Merckelbach, Otgaar, \& Meijer, 2017).

Finally, the Dark Triad traits showed significant correlations with the two dimensions of the Interpersonal Circumplex, named as the Agency and the Communion axes (Wiggins, 1979). People who are high in the three traits were also be located in a high agency and low communion (Jones \& Paulhus, 2011) so they seek autonomy and superiority rather than a deep connection with other people (Wiggins, 1979). Similar to the personality models discussed previously, the Dark Triad traits differed on the facet level (Jones \& Paulhus, 2011). In conclusion the Dark Triad traits share some common correlations with the dimensions of the personality while they have different relationships at the facet level of the major personality models.

\section{Facets of the Dark Triad Traits}

Despite the emphasis on the necessity to include the facets of Narcissism, Machiavellianism, and Psychopathy in the study of Dark Triad by many researchers (e.g., Furnham, Richards, \& Paulhus, 2013; Rauthmann \& Kolar, 2012), most studies measured them as a composite score (e.g.; Aghababaei \& Błachnio, 2015; Birkás, Gács, \& Csathó, 2016; Noser, Zeigler-Hill, \& Besser, 2014).
Facets of Narcissism. Although various propositions have been made for the factor structure of the Narcissism only two of them have been recognized by researchers. One of them suggested by Ackerman et al. (2011) including the "Leadership/Authority", "Grandiose Exhibitionism", and "Entitlement/Exploitativeness" facets. Considering their relationships with the other constructs (e.g.; Buelow \& Brunell, 2014; Clarke, Karlov, \& Neale, 2015; Hill \& Roberts, 2012; Zeigler-Hill \& Vonk, 2015), the most adaptive facet is the Leadership/Authority and the least adaptive facet is Entitlement/ Exploitativeness. Third facet named as Grandiose Exhibitionism is located in between the two facets. Second factor structure distinguishes "grandiose" and "vulnerable" Narcissism. While Grandiose Narcissism is characterized by arrogance, extraversion, and exploitation, Vulnerable Narcissism is described as being fragile, introverted, and neurotic (Giacomin \& Jordan, 2016).

Facets of Psychopathy. "Primary" and "secondary" distinction of psychopathy (Berg et al., 2013) is the one that has driven the most research attention. While Primary Psychopathy involves characteristics such as fearlessness, manipulation, callousness, and ability to regulate emotions, Secondary Psychopathy is defined by impulsivity, anxiety, and aggressive behaviors (Berg et al., 2013; Lee \& Salekin, 2010). Primary psychopathy involves more adaptive characteristics in comparison to secondary psychopathy (e.g.; Johnson, Beehr, \& O'Brien, 2015). Another widely known conceptualization of Psychopathy includes four facets which are "Interpersonal", "Affective", "Lifestyle", and "Antisocial" (Hare \& Neumann, 2008). The facets of Interpersonal and Affective have similar characteristics with the Primary Psychopathy while the facets of Lifestyle and Antisocial have similar characteristics with the Secondary Psychopathy (Hare \& Neumann, 2008).

Facets of Machiavellianism. There is a limited research about the factor structure of Machiavellianism. Originally, Christie and Geis (1970) considered Machiavellianism with three facets including "Manipulative Tactics", "Cynical View of Human Nature", and "Disregard for Conventional Morality". In one of the studies, Machiavellianism divided into two facets which are "Tactics" and "Views" (Monaghan, Bizumic, \& Sellbom, 2016). Another study found a four-factor solution including "Positive Interpersonal Tactics", "Negative Tactics", "Positive View of Human Nature", and "Cynical View of Human Nature" (Corral \& Calvete, 2000). In conclusion more research is needed to determine the factor structure of Machiavellianism. 


\section{Common Measures Used in Measuring the Dark Triad Traits}

There are two major ways of measuring the Dark Triad traits, one by composite scores and one by separate measures for each triat. For the composite scores there are two frequently used inventories in the literature. Dirty Dozen developed by Jonason and Webster in 2010 which is a quite short inventory with 12 items. However there are some criticisms related to the adequacy of the psychometric properties of the scale (Furnham, Richards, \& Paulhus, 2013). Short Dark Triad (SD3) is another questionnaire developed by Jones and Paulhus in 2014 (Furnham, Richards, \& Paulhus, 2013; Muris, Merckelbach, Otgaar, \& Meijer, 2017) with 27 items and described as having better psychometric properties compared to the previous inventory (Muris, Merckelbach, Otgaar, \& Meijer, 2017).

Some researchers prefer to measure the Dark Triad traits separately, so use single inventories with high reliability and validity.For measuring sub-clinical Narcissism, the 40-item Narcissistic Personality Inventory (NPI) developed by Raskin and Hall in 1979 is used frequenlty (Furnham, Richards, \& Paulhus, 2013; Paulhus \& Williams, 2002). For measuring Machiavellianism, 20-item Mach-IV is the standard measure that was created by Christie and Geis in 1970 (Furnham, Richards, \& Paulhus, 2013; Paulhus \& Williams, 2002). For sub-clinical Psychopathy, the scale with 64-item Self-Report Psychopathy Scale (SRP-III) developed by Paulhus, Neumann, and Hare in 2009 is used frequently (Furnham, Richards, \& Paulhus, 2013; Muris, Merckelbach, Otgaar, \& Meijer, 2017; Paulhus \& Williams, 2002).

\section{Relationship betwen the Dark Triad Traits and Coping Styles}

Coping is a crucial resource which has a potential to reduce the negative effects of stressful situations and the choice of coping styles depends on the personality besides many other factors (Birkás, Gács, \& Csathó, 2016). In general, task-focused coping is considered to be more adaptive than emotion-focused or avoidance coping (Endler \& Parker, 1994) since task-focused coping has a higher correlation with psychological well-being compared to the other two coping styles (Endler \& Parker, 1990). According to the literature, people who have higher scores in any of the Dark Triad traits are not very successful in selecting adaptive coping styles when dealing with stress. Narcissism is the most adaptive one, Psychopathy is the most maladaptive, and the Machiavellianism falls in between the two traits. Studies showed that both Machiavellianism and Psychopathy, but not Narcissism, were negatively related to task-focused coping (Birkás, Gács, \& Csathó, 2016) and Psy- chopathy was positively related to emotion-focused and avoidance coping styles (Hasking, 2007; Pastwa-Wojciechowska, Kaźmierczak, \& Błażek, 2012). Moreover, although Machiavellians do not seek social support in a stressful situation, they engage in positive reappraisal (Birkás, Gács, \& Csathó, 2016) and Narcissists show substance use and risky behaviors (Kealy, Ogrodniczuk, Rice, \& Oliffe, 2017), but they also use adaptive coping strategies like planful problem solving and self-controlling (Birkás, Gács, \& Csathó, 2016).

Moreover several studies showed that for different facets of the Dark Triad traits people may prefer to use different coping styles. For instance, Vulnerable Narcissists were more likely to utilize denial and behavioral disengagement compared to Grandiose Narcissists (Fernie, Fung, \& Nikčević, 2016), Secondary Psychopathy predicted coping through substance use more than Primary Psychopathy (Gillen, Barry, \& Bater, 2016), and Primary and Secondary Psychopaths differed in their coping styles when faced with feelings of shame (Campbell \& Elison, 2005). Nevertheless, more research is needed in order to clarify the specific differences in coping among different facets of the Dark Triad traits.

\section{Relationship between the Dark Triad Traits and Well-Being}

It is a well known fact that personality plays a significant role in physical and psychological well-being. Based on the studies about well being and the Dark Triad traits, there are negative relationship between three traits and well-being, but Psychopathy has the worst relationship, followed by Machiavellianism and Narcissism (Muris, Merckelbach, Otgaar, \& Meijer, 2017). Studies showed that Psychopathy had a negative relationship not only with subjective health indicators, but also with protective health behaviors (Hudek-Knežević, Kardum, \& Mehić, 2016). Also it was related to lower life expectancy (Jonason, Baughman, Carter, \& Parker, 2015), greater vulnerability to stress (Noser, Zeigler-Hill, \& Besser, 2014), negative affect and depression (Love \& Holder, 2014). Although Machiavellians were shown to have decreased risk of injuries, they also had decreased positive mood (Hudek-Knežević, Kardum, \& Mehić, 2016) and were more likely to be depressed (Y1lmaz \& Yavas, 1996). Narcissism was positively related to both hedonic and eudemonic well-being (Aghababaei \& Błachnio, 2015), higher life expectancy (Jonason, Baughman, Carter, \& Parker, 2015), and decreased risk of skin diseases (Hudek-Knežević, Kardum, \& Mehić, 2016). Moreover Narcissistic adults were more likely to be perceived as neurotic (Hill \& Roberts, 2012) and Narcissistic male prisoners were more psychologically distressed (Ireland, Brown, \& Ballarini, 2006). 


\section{Discussion}

In this literature review, the definitions, similarities, and differences of Narcissism, Machiavellianism, and Psychopathy, their facets, the most commonly used measures, their relationships with coping styles and psychological well-being were discussed in detail. It can be concluded that although the Dark Triad traits share some common features, it is required to measure them separately as they differ in some significant ways. Considering their relationships with coping styles and psychological well-being indicators, the level of darkness of the three traits are not the same so that psychopathy is located at the darkest end, narcissism at the lightest, and Machiavellianism falls in between the two. Despite this difference in the level of darkness and the positive findings regarding narcissism's relation to well-being, the negative psychosocial consequences associated with each of the Dark Triad traits still predominate over positive ones in order to render them maladaptive.

In addition to that, also the facets of narcissism and psychopathy differ in terms of adaptiveness, but more research needs to be conducted in order to distinguish among the different facets in a more elaborate manner. Moreover, there is insufficient research to clarify the factor structure of Machiavellianism. The most important reason for investigating the different facets of the Dark Triad traits may be to distinguish between the adaptive and maladaptive facets of each trait and to develop an awareness raising and support programs to make these individuals acquire adaptive coping skills. It will not only be helpful in making people possessing Dark Triad traits more psychologically healthy but will also be likely to reduce their malevolent behaviors since people coping with stressors in a more successful way are expected to engage in antisocial acts less. 